Published in "Tectonophysics 593: 1-19, 2013"

which should be cited to refer to this work.

\title{
The formation of Pangea
}

\author{
G.M. Stampfli ${ }^{\text {a,* }}$, C. Hochard ${ }^{\text {a }}$, C. Vérard ${ }^{\text {a }}$, C. Wilhem ${ }^{\text {a }}$, J. vonRaumer ${ }^{\text {b }}$ \\ a Earth Sciences Institute (ISTE) Geopolis, UNIL, CH-1015 Lausanne, Switzerland \\ b Sciences de la Terre, Université de Fribourg, CH-1700 Fribourg, Switzerland
}

The making of Pangea is the result of large-scale amalgamation of continents and micro-continents, which started at the end of the Neoproterozoic with the formation of Gondwana. As pieces were added to Gondwana on its South-American, Antarctica and Australia side, ribbon-like micro-continents were detached from its African and South-Chinese side: Cadomia in the late Neoproterozoic, Avalonia and Hunia in the Ordovician, Galatia in the Devonian and Cimmeria in the Permian. Cadomia was re-accreted to Gondwana, but the other ribbon-continents were accreted to Baltica, North-China, Laurussia or Laurasia. Finding the origin of these numerous terranes is a major geological challenge. Recently, a global plate tectonic model was developed together with a large geological/geodynamic database, at the Lausanne University, covering the last 600 Ma of the Earth's history. Special attention was given to the placing of Gondwana derived terranes in their original position, using all possible constraints. We propose here a solution for the Variscan terranes, another paper deals with the Altaids. The Galatian super-terrane was detached from Gondwana in the Devonian, during the opening of Paleotethys, and was quickly separated into four sub-terranes that started to by-pass each other. The leading terranes collided at the end of the Devonian with the Hanseatic terrane detached from Laurussia. In the Carboniferous, Gondwana started to impinge onto the amalgamated terranes, creating the Variscan chain and the Pangean super-continent. East of Spain Paleotethys remained opened until the Triassic, subducting northward under Laurasia. Roll-back of the Paleotethyan slab triggered the collapse of most of the European Variscan orogen, which was replaced by series of Permian rifts, some of them becoming oceanized back-arc basins during the Triassic. Major force changes at the Pangean plate limits at the end of the Triassic provoked its break-up, through the opening of the proto-Caribbean, central-Atlantic, Alpine-Tethys oceanic seaways.

\section{Contents}

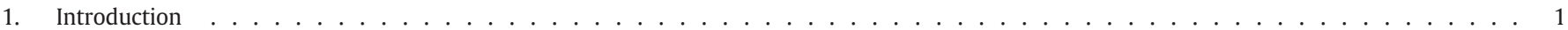

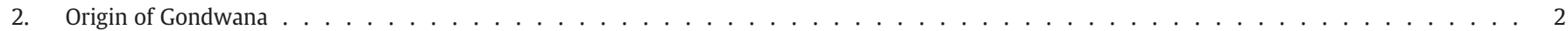

3. Cadomia, Avalonia, Hunia and Gondwana . . . . . . . . . . . . . . . . . . . . . . . . . . . . . . . . . . . . . . . . . . . . . . . . . . . . . . . . . . . . . .

4. Wander path of Gondwana and Eo-Variscan events . . . . . . . . . . . . . . . . . . . . . . . . . . . . . . . . 7

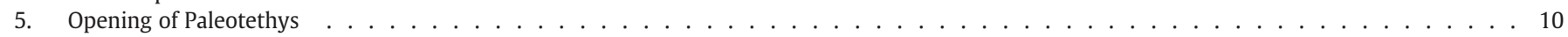

6. The Galatian superterrane accretion to Eurasia . . . . . . . . . . . . . . . . . . . . . . . . . . . . . . . . 10

7. Post-Variscan extensional events . . . . . . . . . . . . . . . . . . . . . . . . . . . . . . . . . . . . . . . . . 13

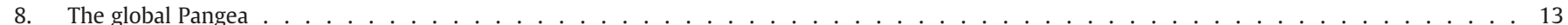

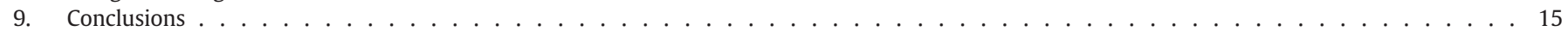

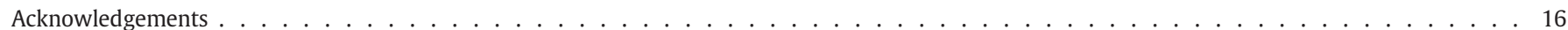

References . . . . . . . . . . . . . . . . . . . . . . . . . . . . . . . . . . . . 16

\footnotetext{
* Corresponding author. Tel.: +4127565 3427.

E-mail addresses: gerard.stampfli@unil.ch (G.M. Stampfli), juergen.vonraumer@unifr.ch (J. vonRaumer).
}

\section{Introduction}

Pangea reached its final shape at the end of the Triassic, following a long history of terranes and continent accretion. The timing of these collisions is usually quite well known from sedimentary and metamorphic records, what is less clear is the kinematics of the terranes involved in these collisions. 
In a new model developed at UNIL these last 10 years, a database including a wide range of constraints was used to produce a global plate tectonic model starting at $600 \mathrm{Ma}$ (Hochard, 2008). More than one thousand "geodynamic units" (GDU) were defined based on their present day geological history, and then assembled as building stones to form terranes, according to geodynamic scenario in space and time (Fig. 1 and Table 1 as an example). Using the synthetic isochrones methodology (Stampfli and Borel, 2002), plates were reconstructed by adding/removing material, along plate limits. Plate velocities are major constraints in the kinematics of the involved terranes and continents and were closely monitored.

This was an iterative process where geological data were always put forwards, but at a certain stage the model is also becoming a predictive tool, enabling to make choices according to plate tectonic principles (Wilhem, 2010). Having a global model in hand, it is also possible to derive the main forces acting at the plate boundaries (Vérard et al., 2012a), and this can be challenged through the analysis of geological data.

The full global model is reached around $520 \mathrm{Ma}$, enabling the exact measure of oceanic versus continental areas from that time onward, as well as the ratio of old versus new oceanic crust (Hochard et al., in prep.). The long-term eustatic variations curve derived from a $3 \mathrm{D}$ version of the model is very similar to the generally accepted long-term curve from the literature (Vérard et al., in prep.). Our curve largely depends on the many plate tectonics options that were discussed and chosen for these 600 Ma years of Earth's history.

Large portions of the model have already been published (e.g. Bagheri and Stampfli, 2008; Bandini et al., 2011; Bonev and Stampfli, 2011; Chablais et al., 2011; Ferrari et al., 2008; Meinhold et al., 2010; Moix et al., 2008; Stampfli and Hochard, 2009; Vérard et al., 2012b; Wilhem et al., 2012). Regarding the Variscan cycle, several papers have been published (e.g. Stampfli et al., 2011; von Raumer and
Stampfli, 2008; von Raumer et al., 2009) mainly centred on the place of the Alpine basements in the Variscan orogen, and we intend here to enlarge this discussion to present a new overview of the plate tectonics mainly for the Paleozoic times of the Variscan-Tethyan area.

Two recent meetings were devoted to the Variscan cycle, one in Madrid in 2011 (Gutiérrez-Marco et al., 2011), and one in Sassari in 2012 (Géologie de la France, 2012), in which many new data were presented, and we want to show here how they can be integrated in our model and where are the remaining challenges.

\section{Origin of Gondwana}

The history of amalgamation of Gondwana has been heavily treated in the literature, and is still a matter of strong debate. The model presented herein is therefore tentative and not definitive, and we provide the reader with a large number of key references.

The present model for the amalgamation of Gondwana strongly relies on the linkage in space and time of many ophiolitic sutures (Fig. 2). Many sutures (in blue in Fig. 2) have collision ages older than our first reconstruction at $600 \mathrm{Ma}$, and crustal fragments, therefore, are already shown amalgamated. Such sutures include those in the Nubian area (ca. 710-750 Ma in the Onib-Sol Hamed zone; Meert, 2003), and all along the western side of the east Pan-African orogeny (from ca. $680 \mathrm{Ma}$ in the Nabitah zone to $650 \mathrm{Ma}$ in the Urd Al Amar zone and 630-650 Ma in its southern continuation along the Tanzania craton; ages after Meert, 2003 and references therein). Sutures in South America (Paraguai and Araguaia, ca. 635 after Rodrigues et al., 2010), in western Africa (Mauritanides-Bassarides and Rockelides with a collision age ranging between 650 and 600 Ma; e.g. DeAraújo et al., 2010; Lytwyn et al., 2006; Paixão et al., 2008; Rodrigues et al., 2010), and in central Africa (Yaoundé and Central Africa with unclear ages; DeAraújo et al., 2010; Dos Santos

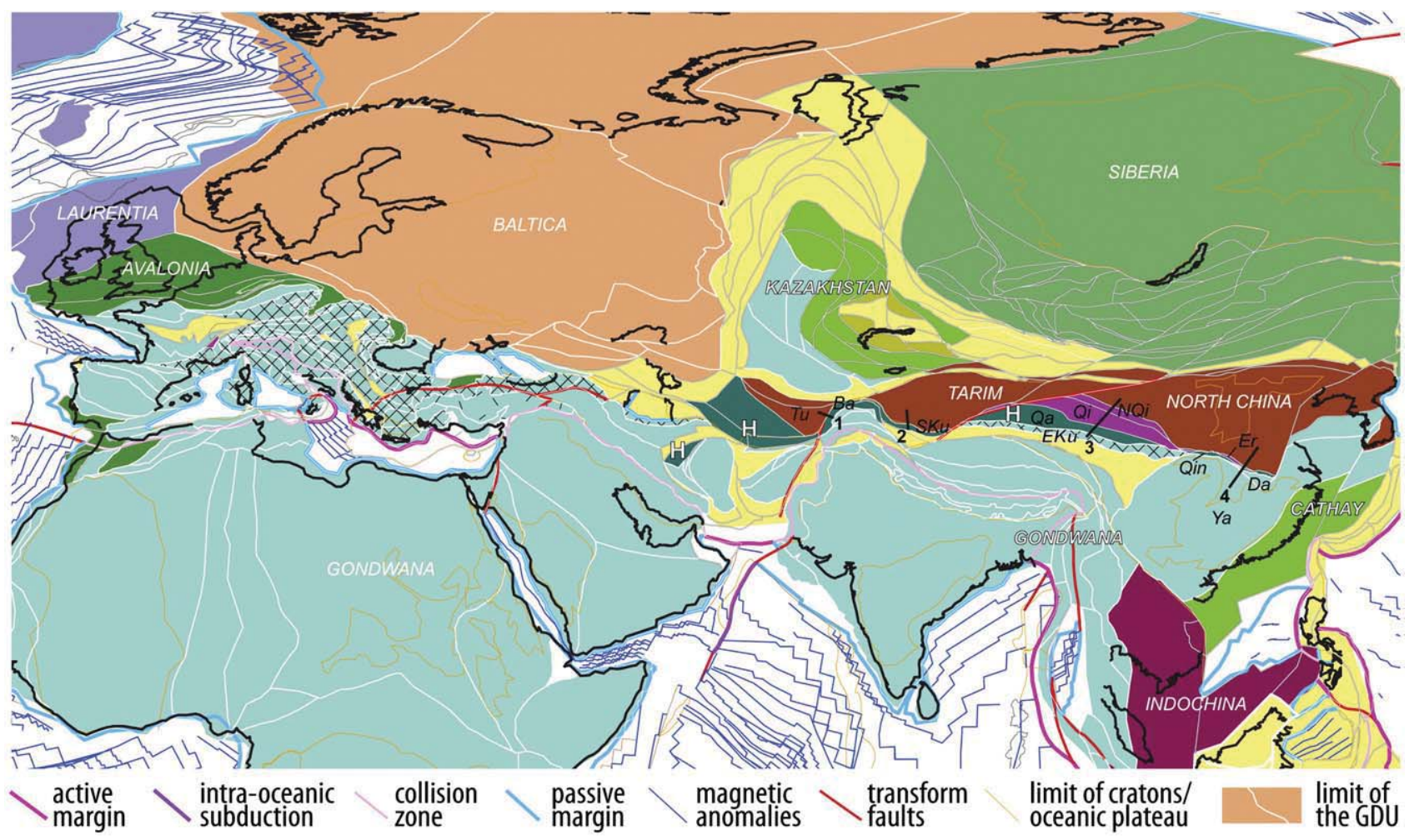

Fig. 1. Present-day map showing GDUs and terranes as defined on the reconstruction of Fig. 4. Transects presented in Table 1: Turan-Pamir (1); Western Kunlun (2); Qilian-Qaidam (3); Qinling-Yangtze (4); GDUs mentioned in Table 1: Tu, Turan; Ba, Badakshan; SKu, South Kunlun; NQi, North Qilian; Qi, Qilian; Qa, Qaidam; EKu, East Kunlun; Er, Erlangping; Qin, Qinling; Da, Dabie and Ya, Yangtze. Light yellow: post-460 Ma formation; dark green, Hunia (H); light blue: Gondwana, its blocks are found also in the Kazakhstan terranes: the criss-cross pattern corresponds to the Intra-Alpine terrane of Fig. 6. This figure is in part derivative from the Neftex Geodynamic Earth Model. @ Neftex Petroleum Consultants Ltd. 2011. 
Table 1

Correlation table of the GDUs making up the highly composite late Paleozoic suture zone south of the North-China, Tarim block. The correlation was done along four transects indicated at the top (see Fig. 1 for location). South of the North-China, Tarim block, a middle Ordovician to Silurian back-arc basin is found, the suture between Hunia and the Chinese blocks is located south of this basin and comprises Devonian HP rocks. A Devonian molasse is also found on Hunia, showing that it was amalgamated to the Chinese blocks at that time. Hunia s.l. is a composite terrane, that comprises an exotic block (Qilian) abandoned during the opening of the Qaidam ocean. The Paleotethys suture zone is located south of Hunia, with Carboniferous to Triassic marine series. This suture zone is also composite, due to the Galatian superterrane smearing along the transform margin of Hunia during the opening of Paleotethys. Pieces of older basements were locally abandoned there, together with elements of the suture of the eastern Rheic ocean. This Devonian suture zone was then affected by the opening of Carboniferous back-arc basins. Turan-Pamir transect: Boulin (1988), Gaetani (1997), Brookfield (2000), Schwab et al. (2004), Natal'in and Śengör (2005); Western Kunlun transect: Mattern and Schneider (2000), Xiao et al. (2002), Wang (2004), Yuan et al. (2004), Jiang et al. (2008) and Lu et al. (2008); Qilian-Qaidam transect: Wu et al. (1993), Yang et al. (1996), Bian et al. (2001), Qian et al. (2001), Yang et al. (2001), Yang et al. (2002), Meng and Ge (2003), Song et al. (2003), Xia et al. (2003), Bian et al. (2004), Shi et al. (2004), Zhai (2004), Liu et al. (2005), Zhang et al. (2005), Hou et al. (2006), Liu et al. (2006b), Menold et al. (2006), Shi et al. (2006), Song et al. (2006), Xu et al. (2006), Yang et al. (2006), Li et al. (2007), Song et al. (2007), Tung et al. (2007), Zhang et al. (2008), Song et al. (2009), Xiao et al. (2009) and Zhang et al. (2009); and OinlingYangtze transect:Yin and Nie (1993), Li (1994), Yu and Meng (1995), Xue et al. (1996a), Xue et al. (1996b), Yin and Nie (1996), Faure et al. (2001), Li et al. (2003), Ratschbacher et al. (2003), Wang and Li (2003), Hacker et al. (2004), Liu et al. (2006a), Ratschbacher et al. (2006), Li et al. (2007), Tang et al. (2007), Yuan et al. (2007), Zhou et al. (2008) and Wu et al. (2009).

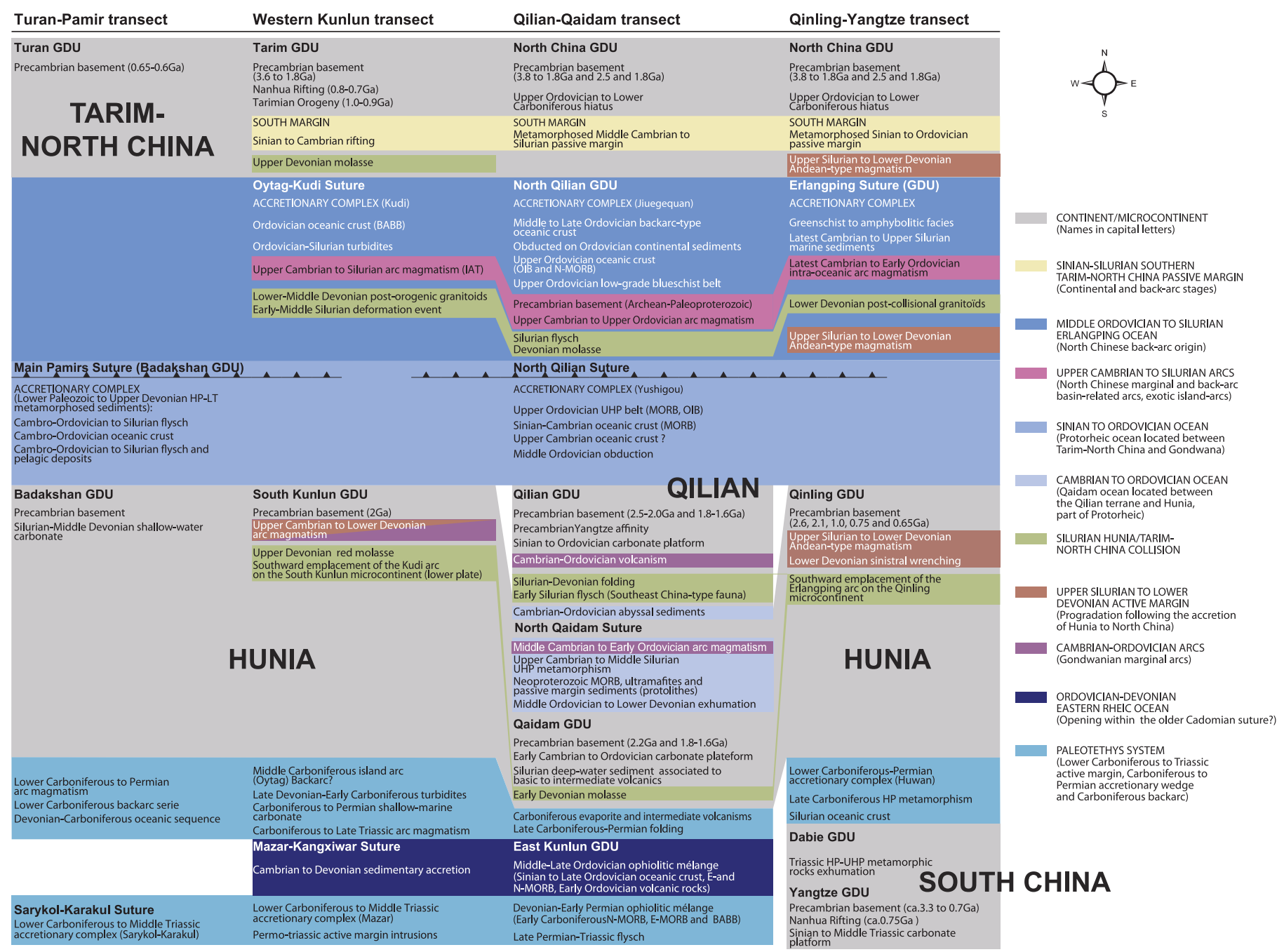

et al., 2008; Owona et al., 2011) are also older than our first reconstruction. However, collision ages cluster around $600 \mathrm{Ma}$ in the Pharusides and Dahomides-Borborema (ca. $620 \mathrm{Ma}$ in the Pharusides and ca. $580 \mathrm{Ma}$ in the Dahomides after DeAraújo et al., 2010; see also a synthesis of the region after Caby, 2003). Following Fitzsimons (2003) and Boger (2011), a suture running between the Antarctica (or Crohn) Craton and the Mawson craton is inferred and thought to be older than $600 \mathrm{Ma}$. The delimitation of that suture is derived from topographic (Etopo1, bedrock surface; Amante and Eakins, 2009), gravimetric (Grace; Tapley et al., 2005) and magnetic (Emag2; Maus et al., 2009) lineaments and is linked to the Darling Fault along the Yilgarn craton in Australia.

The sutures shown in purple (Fig. 2) are latest Neoproterozoic to Early Cambrian in age. In fact, the Paraguai, Brasília, Araçuai, West
Congo belts comprise two age clusters, one around $620 \mathrm{Ma}$ and the second around $570 \mathrm{Ma}$ (e.g. Gray et al., 2006, 2008; Hanson, 2003; Laux et al., 2005; Rodrigues et al., 2010; Veevers, 2007). The first set of ages is interpreted as the collision of intra-oceanic magmatic arcs turning the passive margin (DaSilva et al., 2008) into an active one, and the second set of ages as the final continent-continent collision. The suture of the Paraguay Belt (e.g. Bandeira et al., 2012; Dantas et al., 2009) is linked to the Transbrasiliano Lineament (Ramos et al., 2010), with ages as young as $550 \mathrm{Ma}$. Of similar age (ca. 570-550 Ma), the Betsimisaraka suture in Madagascar (Buchwaldt et al., 2003; Collins et al., 2003; DeWaele et al., 2009; Key et al., 2011) is linked, in the South, to Early Cambrian deformation in the Lützow-Holm Bay and Shackleton Ranges in Antarctica (Leat et al., 2005), and syn-collisional granite intrusion in Iran to the North (e.g. Saki, 2010). 


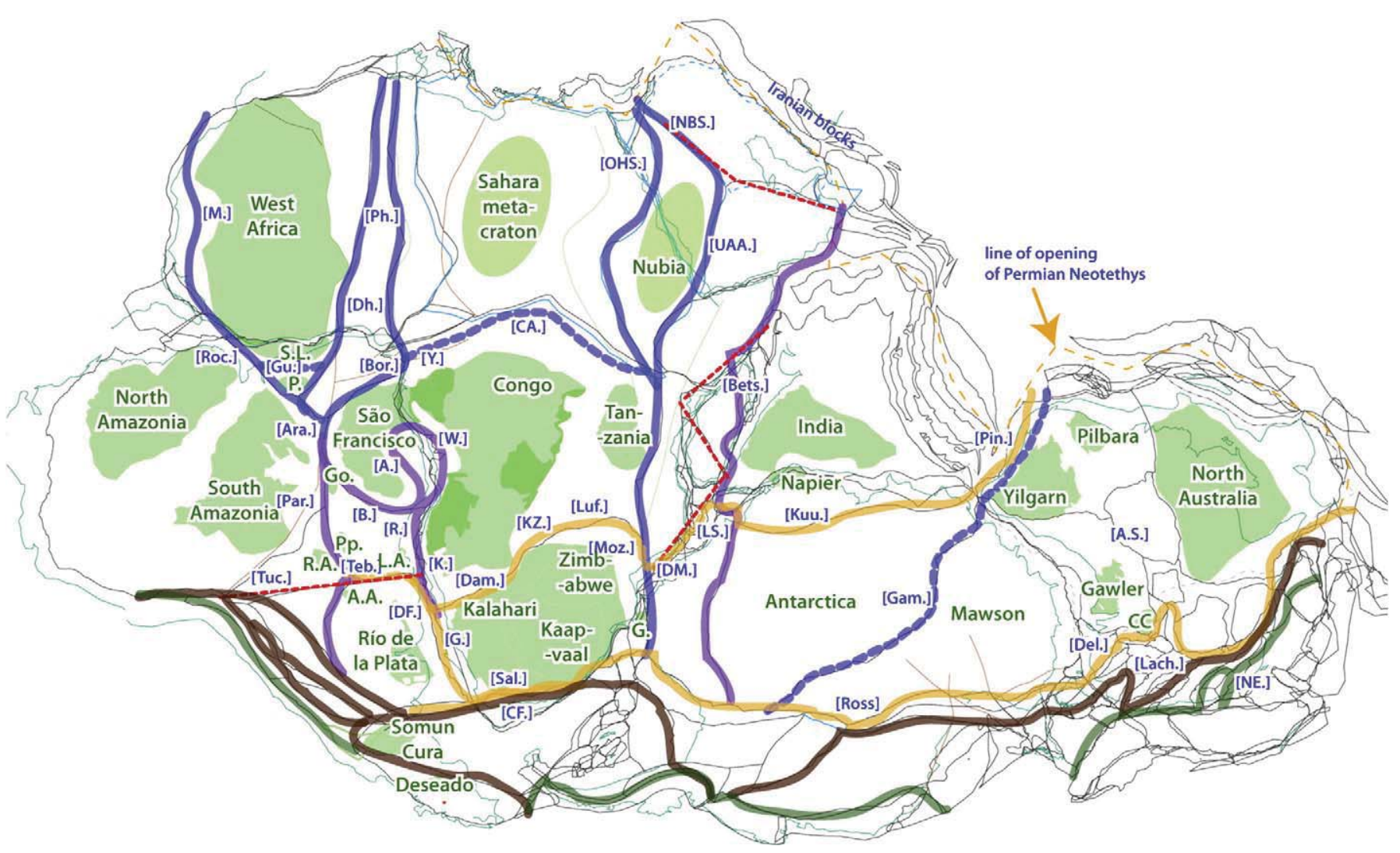

Fig. 2. Reconstruction of Gondwana showing major sutures zones; blue: older than or about 600 Ma; purple: mainly between 550 Ma and 600 Ma; orange: mainly between 500 Ma and $550 \mathrm{Ma}$; brown and green: younger than $500 \mathrm{Ma}$ (or Australides, termed after Vaughan et al., 2005). Blue abbreviations correspond to suture names: [A.], Araçuai; [Ara.], Araguaia; [A.S.], Alice Spring; [B.], Brasília; [Bets.], Betsimisaraka; [Bor.], Borborema; [C.A.], Central Africa; [C.F.], Cape Fold; [Dam.], Damara; [Del.], Delamerian; [D.F], Dom Feliciano; [Dh.], Dahomides; [D.M.], Dronning Maud; [G.], Gariep; [Gu.], Gurupi; [Gam.], Gamburtsev; [K.], Kaoko; [Kuu.], Kuunga; [K.Z.], Katagan-Zambezi; [Lach.], Lachlan; [L.S.], Lützow-Shackleton; [Luf.], Lufilian
Arc; [M.], Mauritanides; [Moz.], Mozambique; [NBS], Nabitah; [N.E.], New England; [OHS], Onib-Sol Hamed; [Par.], Paraguai; [Ph.], Pharusides; [Pin.], Pinjarra; [R.], Rebeira; [Roc.], Rockelides; [Ross], Ross; [UAA.], Urd Al Amar; [Sal.,], Saldanha; [Tuc.], Tucavaca; [Teb.], Tebicuary; [W.], West Congo; [Y.], Yaoundé. Green names and abbreviations correspond to cratonic areas: A.A., Ascuncíon Arch; C.C., Curnamona craton; G., Grunehogna craton; Go., Goiás craton; LA. Luís Alvez craton; P., Parnaíba craton; Pp., Paranapanema meta-craton; R.A., Rio Apa meta-craton; S.L., São Luís craton. (Lat-Long projection). This figure is in part derivative from the Neftex Geodynamic Earth Model. @ Neftex Petroleum Consultants Ltd. 2011.

The last series of sutures, which must be considered when talking about the final assembly of Gondwana (e.g. Yoshida et al., 2003 and all references therein) are those shown in orange (Fig. 2). Those sutures have ages ranging from ca. $550 \mathrm{Ma}$ in the Pinjarra orogen (Australia; e.g. Fitzsimons, 2003; Wingate and Evans, 2003), to 520-530 Ma in the Kuunga orogen (Antarctica; e.g. Harley, 2003; Zhao et al., 2003), and to 550-500 Ma in the Lufilian Arc, Katagan-Zambesi Belt and Damara orogen (Africa; Gray et al., 2008, and references therein). The suture running from the Saldanha orogen (Africa), to the Ross orogen (Antarctica), and to the Delamerian orogen (Australia) display mostly ages between $550 \mathrm{Ma}$ and $500 \mathrm{Ma}$, but is more commonly associated with the formation of the Australides (Vaughan et al., 2005 and all references therein), which are often considered as peri-Gondwana events.

\section{Cadomia, Avalonia, Hunia and Gondwana}

One of the main challenges of these reconstructions was to find the homeland of small terranes. For the Paleozoic this is even more difficult as some of these have been re-displaced after a former amalgamation. The «classical» Variscan models (e.g. Franke, 2000; Matte, 1991, 2001), most of them of continental drift type, consider that the present juxtaposition of terranes allows for deriving geodynamic relationships for adjacent blocks. That might be true for the final closing of the Rhenohercynian marine space, but we propose that in such a complex orogen, juxtaposition is suspicious, and most terranes are displaced or exotic to each other. These classical models see the collision of Gondwana derived terranes in the Early Carboniferous as the final collision of Gondwana, thus totally ignoring the presence of Paleotethys. This is where a global plate tectonic model comes of use, as it has some predictive qualities, which impose some geometrical and geodynamical constraints; mainly the necessity to keep continuity and coherency along plate limits, and not just move continents around the globe. This was done and redone during the last ten years for the blocks involved in the Variscan collision (Stampfli et al., 2002, 2011; von Raumer et al., 2002, 2009), and their placing along the margin of Gondwana.

Between 600 and $500 \mathrm{Ma}$, the Cadomian arc system and the continents composing Gondwana were amalgamated. The last Pan-African magmatic events are thus synchronous to the Cadomian ones. The Cadomian arc system was partly derived from North China and Gondwana at first, the arc was linked westward with Avalonia and the Amazon craton (Linnemann et al., 2007 and the many references therein). Around $540 \mathrm{Ma}$, all these elements were in collision, forming a proto-Gondwana landmass. It is only after $500-510$ Ma that Gondwana finally included continents such as Antarctica and Australia, and terranes such as the Himalayan domain and Pampia in SouthAmerica. Elements related to Australia, such as the High-Himalaya, Indochina and Cathay blocks were accreted during the late Cambrian and Ordovician to India/South-China (Figs. 3 and 4). South-China and all the blocks that will be involved in the Variscan orogeny were already part of Gondwana since the late Neoproterozoic, as northern 


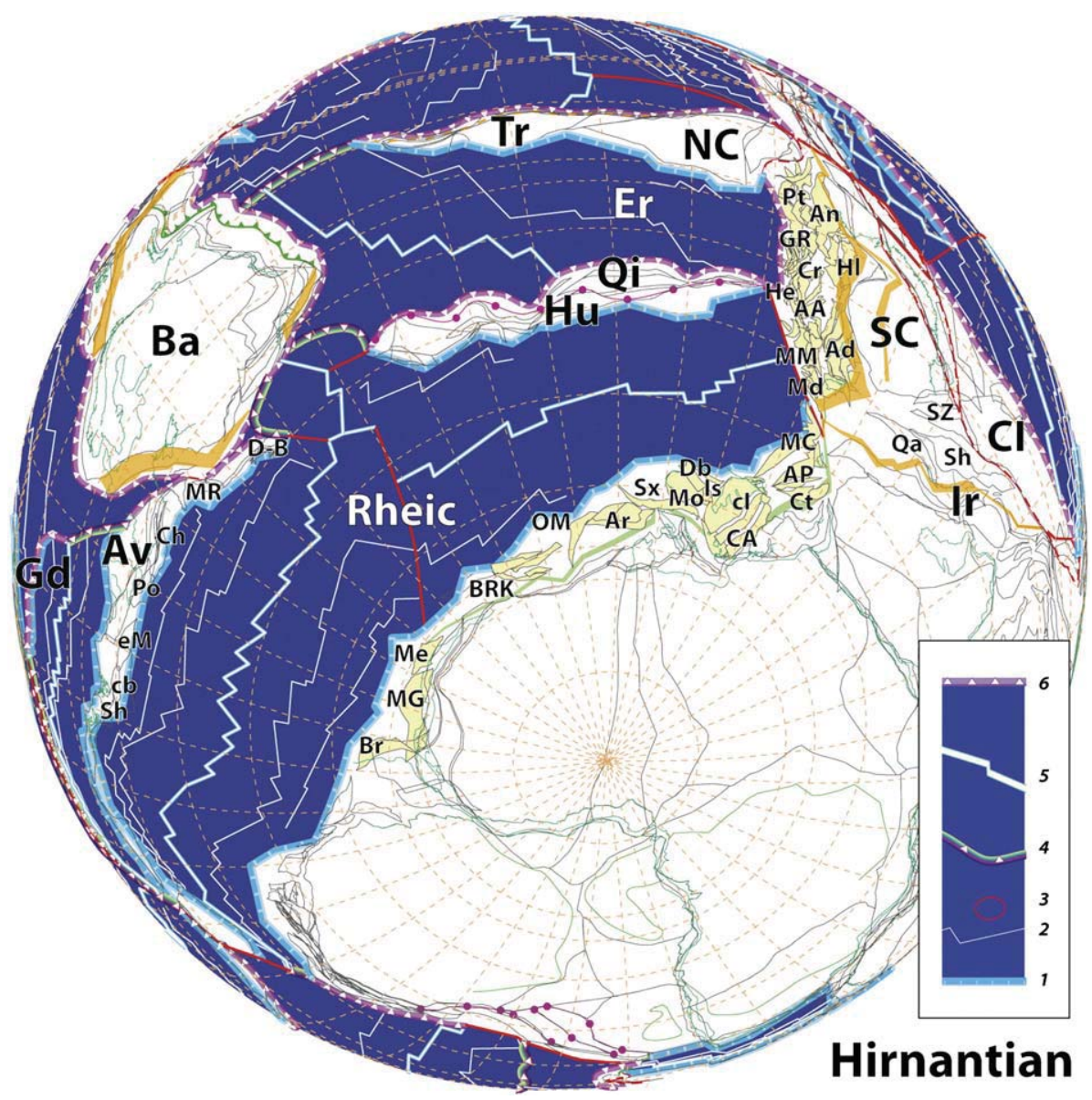

Fig. 3. Global reconstruction for the Late Ordovician, showing the location along Gondwana of the blocks (GDUs) involved in the Variscan chain (modified from Stampfli et al., 2011). Av, Avalonia; Ba, Baltica; CI, Cathay-Indochina; Er, Erlangping ocean; Gd, Gander arc; Hu, Hunia; Ir, Iranian blocks; NC, North-China; Oi, Oilian; SC, South-China: Oa, Oamdo; SZ, Songlia-Zongza; Sh, Shan; Tr, Tarim. The Galatian superterrane (GDUs in yellow) is made of four sub-terranes (see also Figs. 4 and 6), from left to right: the Meguma terrane: Br, Brunswick; MG, Meguma; Me, Moroccan Meseta; the Armorica terrane: BRK, Betics-Rif-Kabbilies; OM, Ossa Morena; Ar, Armorica s.str; Sx, Saxothuringia; Mo, Moesia; Db, Dobrogea; Is, Istanbul; the Ibero-Ligerian terrane: cl, central Iberia; CA, Cantabria; Ct, Catalunia; AP, Aquitaine-Pyrenees and Corsica; MC, Massif Central; Md, Moldanubian; the intra-Alpine terrane: MM, Montagne Noire-Maures; Ad, Adria, Sardinia and outer Dinarides; AA, Austroalpine; He, Helvetic; Cr, Carpathian; Hl, Hellenidic; GR, Getic-Rhodope; An, Anatolic; Pt, Pontides (Karakaya). The GDUs forming the future Hanseatic terrane along Avalonia are: Sh, Sehoul block; cb, coastal block; eM, eastern Meseta; Po, south Portuguese; Ch, Channel; MR, mid-German rise; D-B, Dacides-Bucovinian. Major rifts are shown in light orange. Legend: 1 - passive margin, 2 - synthetic anomaly, 3 - seamount, 4 - intra-oceanic subduction zone, 5 - mid-ocean ridge, 6 - active margin. This figure is in part derivative from the Neftex Geodynamic Earth Model. @ Neftex Petroleum Consultants Ltd. 2011.

India (lesser Himalaya), Iran-Afghanistan and South-China (Yangtze block) shared a common Ediacaran-Cambrian carbonate platform (Hamdi et al., 1989; Jiang et al., 2003).

This has quite some bearing on zircon distribution (e.g. GutiérrezAlonso et al., 2007; Linnemann et al., 2007, 2008), pan-African zircons could also be Cadomian, and old basements are not found only in Africa, but also in China, Australia, etc.... (see age indications for the $\mathrm{N}$-Chinese and Hunia blocks basement on Table 1 as examples). The placing of Gondwana derived terranes was often done through comparison of zircon distribution, but only using the African, SouthAmerican references (e.g. Keppie et al., 2003; Martínez Catalán et al., 2004). It is obvious that such a large continent as Gondwana had developed large river systems, therefore, zircon distribution has to be used with caution (e.g. Meinhold et al., 2013; Pereira et al., 2012b).

Our placing of Gondwana derived terranes is using as many constraints as possible, paleogeographic markers such as carbonate distribution in the Cambrian or Devonian, and also geodynamic constraints and drifting patterns derived from the model. For example, we follow here the accepted placing of Avalonia close to west Africa, Amazonia (e.g. Keppie et al., 2003; Murphy et al., 2004, 2006; Nance et al., 2002), but Cambrian to Ordovician similar geodynamic evolution to Avalonia (i.e. opening of the Rheic ocean) found in most European Variscan blocks, implies that these blocks be placed also along the Gondwana margin. In view of the large number of blocks, they must extend along the North-African border and much further east, over thousands of kilometres. And, effectively, if most of these blocks record the opening of an Ordovician ocean, their paleogeography and geodynamic evolution thereafter are becoming quite different; this is obvious when looking at the age/distribution of the Ordovician magmatism.

On Fig. 4, one can see that Avalonia had an eastern equivalent, Hunia, accreted to North China in the Silurian (Table 1). Hunia is on its way to collision with North China, whereas Avalonia is already docking with Baltica. The northern margin of Africa has become a passive margin (confirmed by subsidence pattern of some blocks, von Raumer and Stampfli, 2008), whereas the western South Chinese margin of Gondwana is of transform type, characterized by bimodal magmatism, following subduction related magmatism and deformation, as found in the Alpine basement blocks (von Raumer et al., 2013, and references therein) and neighbouring regions (e.g. Balintoni and Balica, 2013).

Thus, Northern Gondwana was characterized by an active margin setting since at least the early Ordovician, and by the subsequent opening of the Rheic ocean, after a period of subsidence and rifting behind the Ganderia-Avalonia-Hunia arc systems. Consequently, the basement areas of these regions show a strong activity of crustal extension and rifting during the late Cambrian-early Ordovician, accompanied by many intrusions. The detachment of Hunia from 

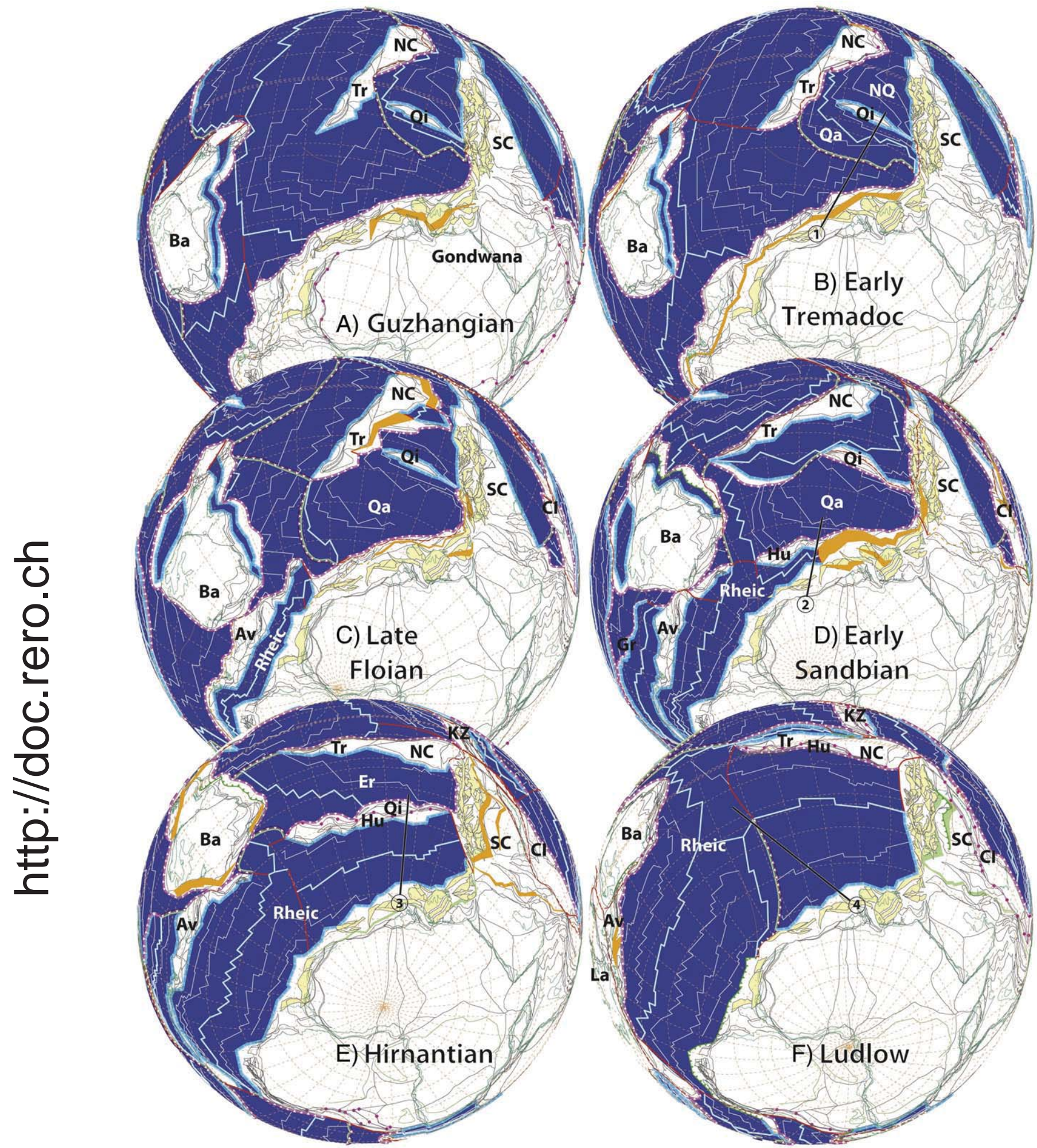

Fig. 4. Modified from Stampfli et al. (2011). The Cambrian opening of back-arc basins (Fig. 1A Guzhangian) resulted in the detachment from the South Chinese segment of the Qilian Terrane. In Fig. 1B, early Tremadoc and C late Floian, the arc migrated alone toward Baltica leaving the Qilian microcontinent surrounded by passive margins. During the late Cambrian and Ordovician time, the migrating arc collided both with the Gondwana and North China margins, turning the latter from passive to active after subduction reversal. The Erlangping back-arc basin then developed within the southern margin of North China (Fig. 1C and D Early Sandbian), and its arc successively collided with the Qilian and future Hunian terranes (Fig. 1D and E, Hirnantian). This amalgamated Hunia-Qilian terrane was accreted in turn to North China (Fig. 1F, Ludlow), and a new active margin developed under North China. Av, Avalonia; Ba Baltica; CI, Cathay-Indochina; Er, Erlangping ocean; Gd, Gander arc; Hu, Hunia; Kz, Kazakhtania; Lg, Ligerian arc; NC, North China; NQ North Qilian ocean; Qa, Qaidam ocean; Qi, Qilian; SC, South China; Tr, Tarim. The Galatian superterrane (in yellow) legend is found on Fig. 3. For cross-sections see Fig. 7. This figure is in part derivative from the Neftex Geodynamic Earth Model. @Neftex Petroleum Consultants Ltd. 2011. 
Gondwana gave birth to the eastern branch of the Rheic ocean, slightly younger (c. $460 \mathrm{Ma}$ ) than the western branch (Rheic s.str. c. $480 \mathrm{Ma}$ ) related to the detachment of Avalonia. Earlier detachment of terrane such as Ganderia from Amazonia around $500 \mathrm{Ma}$ (van Staal et al., 2012) shows that this opening was most likely diachronous, starting first in the west north of South-America, and propagating eastward north of Africa. We consider here that Ganderia and Avalonia drifted together and Avalonia was abandoned during the translation to Laurentia (Fig. 4). In the eastern part of the Gondwana margin, comprising among others the Alpine and Mediterranean domains, the Ordovician active margin started later than in the west and lasted until the middle/late Ordovician.

The opening of the eastern Rheic ocean followed a collision of a North-China derived arc with the Gondwana active margin, such an arc relic is known in the upper nappes of Galicia and dated around $475 \mathrm{Ma}$ (Sanchez Martinez et al., 2012). This collision triggered the inversion of previous Cambrian-Ordovician grabens and produced the widespread Armorican quartzite event (480-465 Ma, e.g. GutiérrezAlonso et al., 2007) in northern Gondwana (von Raumer and Stampfli, 2008). In Spain the Armorican quartzite if often unconformable on older strata due to this pre-Arenig (Floian) deformation phase. But, the ongoing detritic input can also be linked to the shoulder uplift and erosion of the opening Rheic ocean, and to the evolution of the Gondwana border towards a passive margin stage in the middle Ordovician (e.g. McDougall et al., 1987).

Thus, an overall Ordovician geodynamic scenario for the northern Gondwana margin can be constructed (Fig. 4) through the cessation of magmatic activity and the diachronous onset of passive margin settings, related to the opening of the Rheic ocean within the peri-Gondwana cordillera from the late Cambrian in the west to the early Ordovician in the west.

\section{Wander path of Gondwana and Eo-Variscan events}

The source of many Gondwanan magnetic poles is also found in the blocks amalgamated to Gondwana between 600 and 300 Ma mainly those from the Lachlan orogen in Australia and Pampia in Argentina (as discussed in Vérard, 2004, see also below last chapter on global Pangea). To overcome this issue, we constructed a new wander path for Gondwana around three paleo-poles (c. $550 \mathrm{Ma}, 480 \mathrm{Ma}$ and $300 \mathrm{Ma}$ ) generally coherent in the studies of Bachtadze and Briden (1991), Schmidt et al. (1990), Li and Powell (2001), Torsvik and Van der Voo (2002) and McElhinny et al. (2003). In the intervals, we followed a paleogeographic approach similar to Scotese and Barrett (1990). Poles have been constrained by using the worldwide carbonate distribution for the pre-Ordovician, then the Hirnantian pole is constrained by the numerous records of glaciation on Gondwana (e.g. Ghienne, 2011; Fig. 5), and also the main geodynamic events that created kinematic changes, such as the opening of major oceans. But one of the main constraints comes from the velocities implied by such a wander path. Paleomagnetic paths proposed so far imply velocities ranging from $15 \mathrm{~cm} / \mathrm{yr}$ to more than $45 \mathrm{~cm} / \mathrm{yr}$ (Vérard, 2004). We consider such velocities too high or unacceptable for a large continent/plate. Instead we tried to average them to $8-10 \mathrm{~cm} / \mathrm{yr}$. The

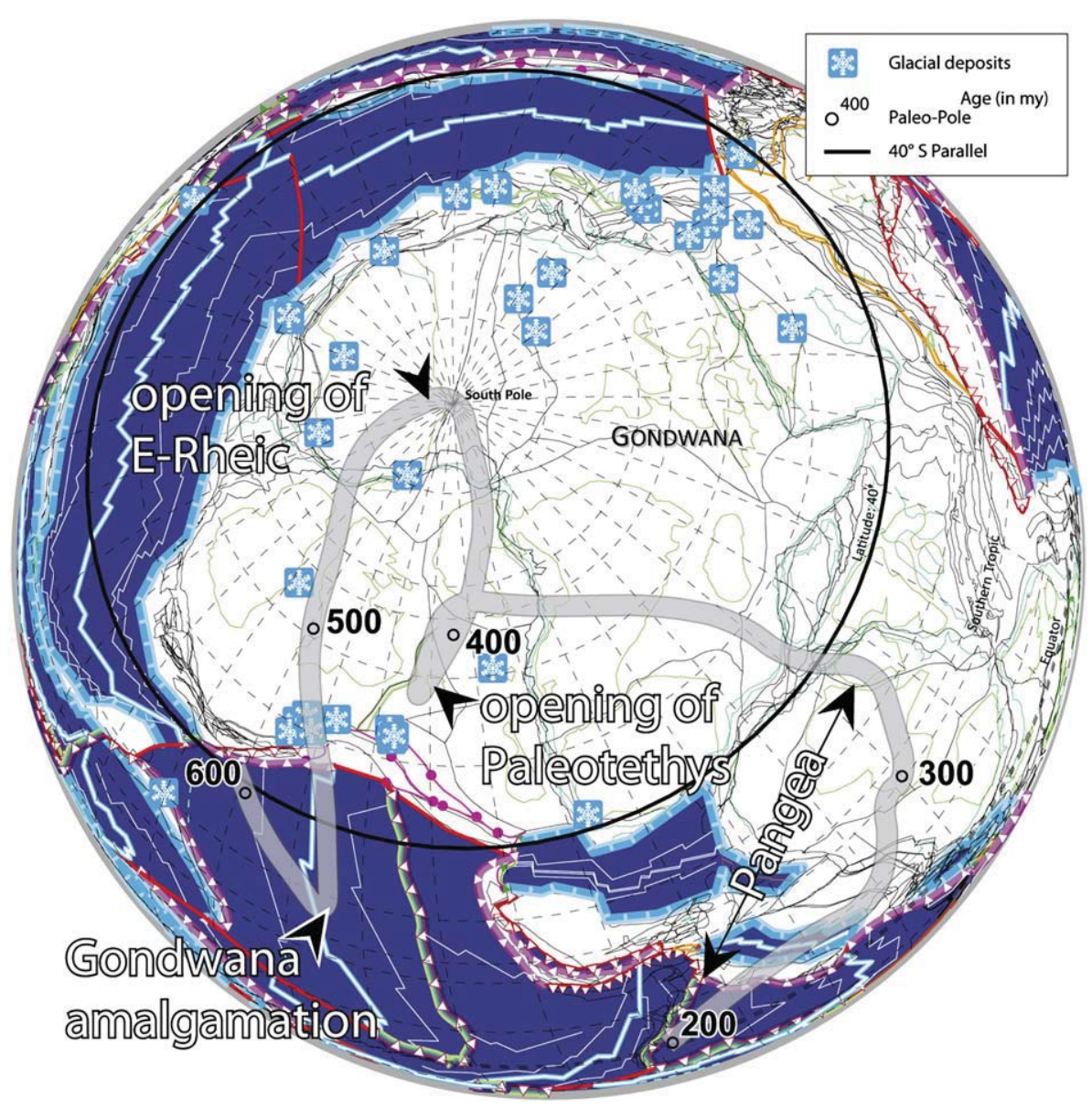

Fig. 5. APWP for Gondwana on a Hirnantian reconstruction. The main changes of direction in the wander path are related to major tectonic events, like the amalgamation of Gondwana in the early Cambrian, the onset of spreading of the Rheic ocean in the middle Ordovician, the onset of spreading of the Paleotethys in the late Devonian, and the amalgamation of Pangea from the late Carboniferous to the late Triassic. This figure is in part derivative from the Neftex Geodynamic Earth Model. @ Neftex Petroleum Consultants Ltd. 2011. 
resulting path (Fig. 5) is in good agreement with the most recent path of Torsvik and Cocks (2011), especially for the middle-upper Ordovician to Upper Carboniferous time span.

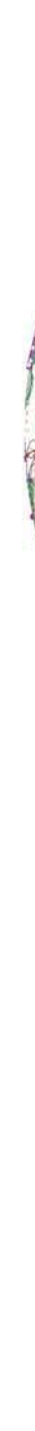

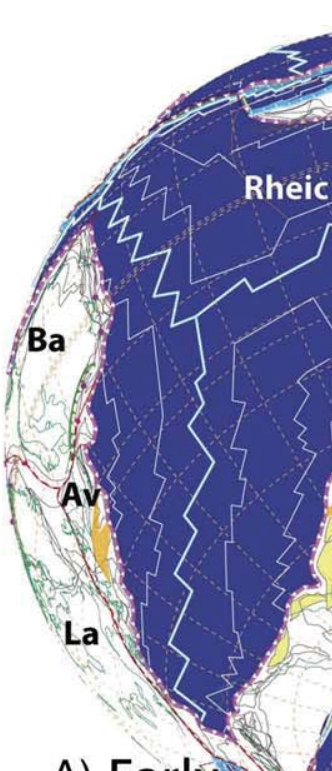

A) Early Emsian

से

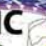

B) Eifeilian

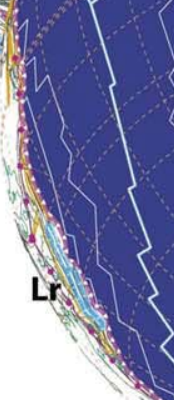

Rheic

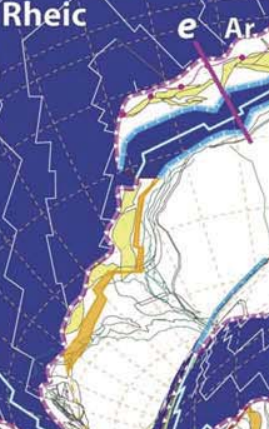

Apparent Polar Wander Paths (APWP) of North-America and Baltica are quite well constrained for the Paleozoic, and our new path for Gondwana allows to reassess some models where collision

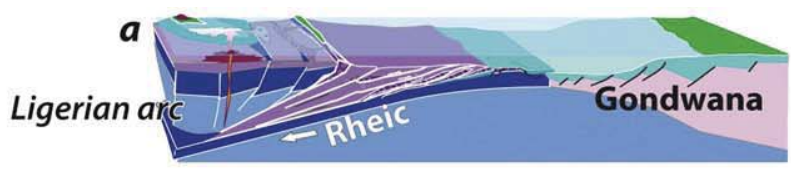

b

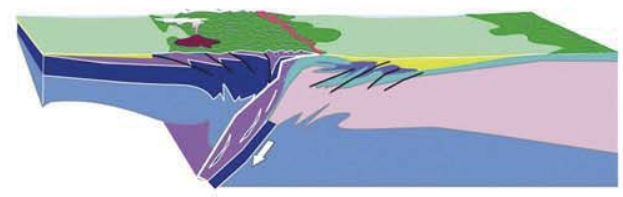

c
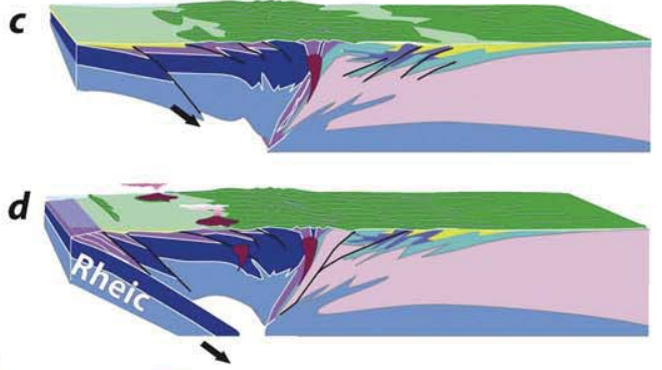

\section{Gondwana}

Sb takest $T$
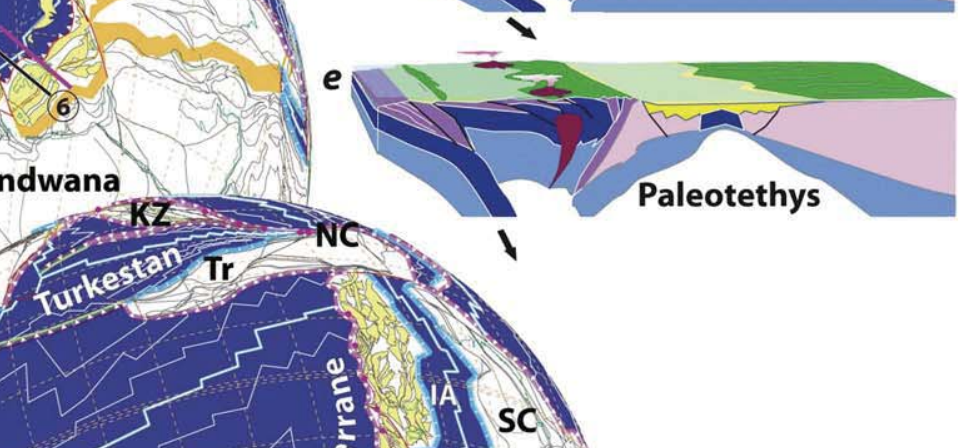

D) Middle

Famennian

C) Early

Frasnian

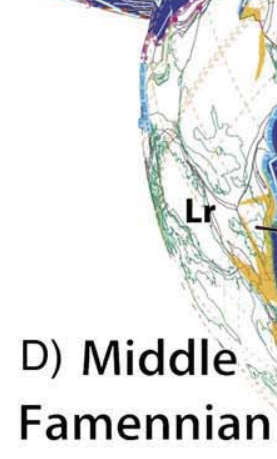


490 Ma Late Cambrian
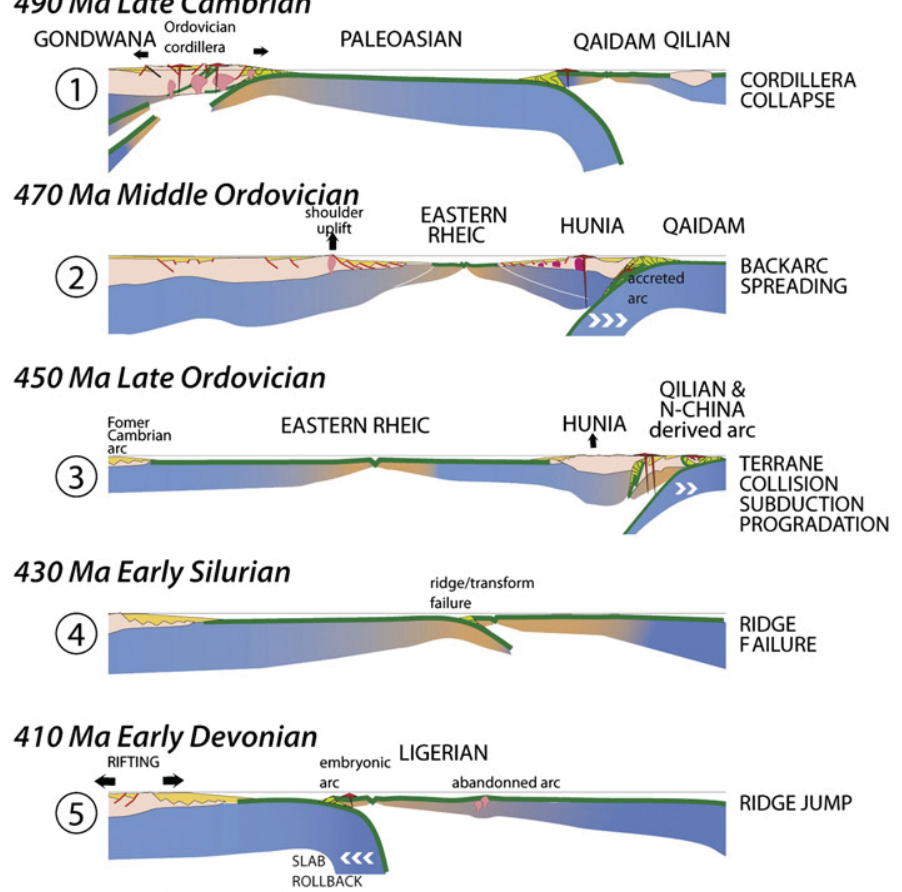

400 Ma Early Devonian GONDWANA

\section{(6)}
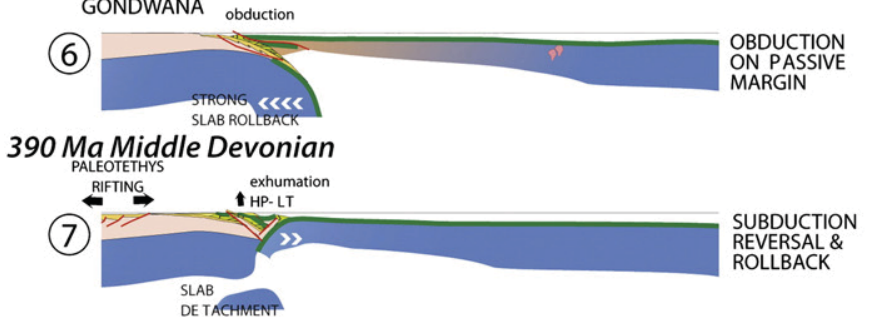

380 Ma Frasnian

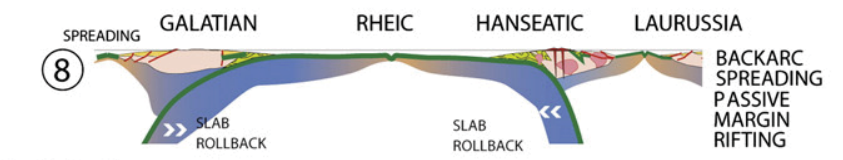

370 Ma Famennian

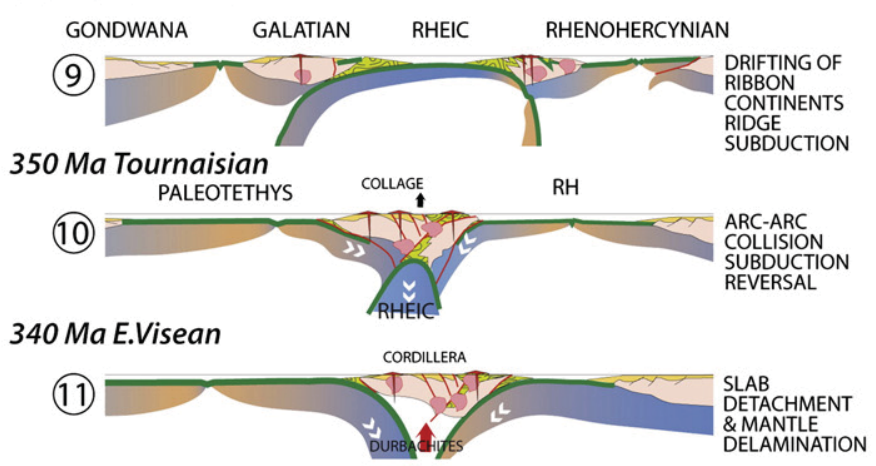

330 Ma L. Visean
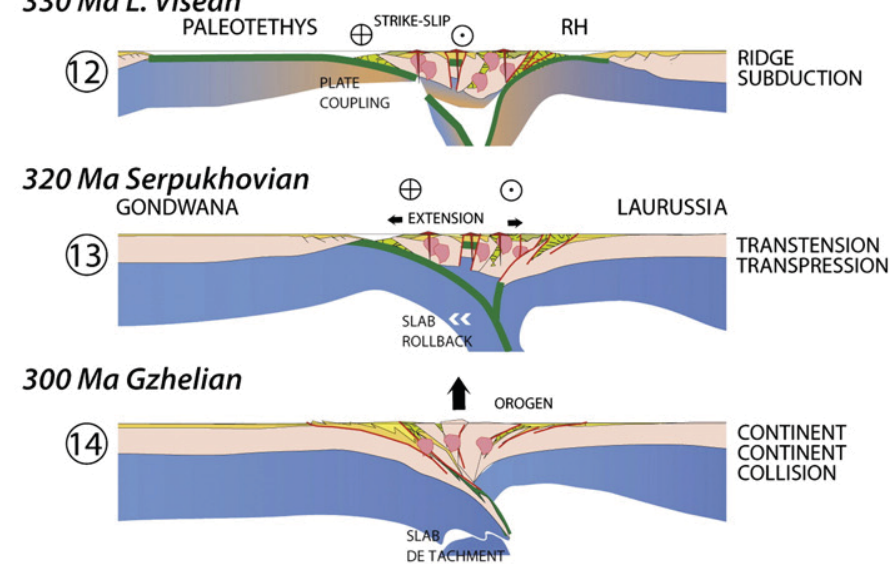

Fig. 7. Cross-section models of the evolution of the Gondwana margin from 490 to 300 Ma (modified from Stampfli et al., 2011). The sections are tied to Gondwana, so the continent to the right is changing through times. For the left part of the figure, North China elements are facing Gondwana, whereas for the right side of the figure, it is Laurussia. Location of the cross-sections is found on Figs. 4, 6 and 8. The horizontal scale is not respected.

of these landmasses are proposed already in the Silurian-Devonian (e.g. Arenas et al., 2009; Keppie et al., 2010; Martínez Catalán et al., 2007, 2009) in order to explain the eo-Variscan HP event found in Spain, France and Germany. The alternative is to place this event on the Gondwana border, a model we already proposed in Stampfli et al. (2002). This first attempt was completely revised in the following years, but the principle stays the same. The Ordovician passive margin created by the opening of the Rheic ocean (East and West), has to be changed into an active margin again, in order to detach all the Variscan blocks from Gondwana and bring them to Laurasia. In doing so, the Paleotethys opened and the Rheic ocean closed. This is one of the very few solutions if we consider the APWP path of Gondwana as redefined here (Figs. 5 and 6).

In Fig. 6, we see that an intraoceanic subduction zone developed in the Rheic ocean, starting from a leaky transform zone, and the associated arc (Lg, Ligerian, Fig. 6A) is progressively colliding with the Gondwana passive margin from west to east. Partial or total obduction of the arc or back-arc domain on the passive margin can be expected (Oman model), then slab detachment was followed by subduction reversal (initially N-dipping then S-dipping, e.g. Massif Central, Lardeaux et al., 2012) and the passive margin plus the obducted material were transformed into an active margin (Figs. 6 and 7). The HP event recorded in many Variscan domains can be related to either the collision of the arc with the passive margin and/or the obduction of the back-arc ridge, and as the phenomenon is diachronous, a relatively large time span of HP can be expected (from $400 \mathrm{Ma}$ to $370 \mathrm{Ma}$ ). In this suture zone, ophiolites can be derived from the upper plate (arc crust, back-arc ridge) but also from the lower plate, the mantle lithosphere of these various units can be juvenile or derived from the toe of the Gondwanan margin and thus, much older. This seems to be confirmed by the recent dating of such rock in Galicia (Sánchez Martínez et al., 2012). Out of sequence thrusting can also be expected in view of the very oblique type of collision north of Africa, whereas a more frontal collision is expected for the intra-Alpine domain located

Fig. 6. Global reconstructions for the Devonian (A, Early Emsian, B, Eifelian, C, Early Frasnian, D, Middle Famennian), showing the progressive opening of Paleotethys and separation of the S-Chinese block from Gondwana (modified from von Raumer et al., 2013). The detached Gondwana terranes formed the Galatian superterrane, made of four terranes: IA, intra-Alpine; IL, Ibero-Ligerian; Ar, Armorica; Mg, Meguma. These are slowly imbricated during their drifting and divided in more sub-blocks (see Fig. 9). Along the Laurussian margin a set of blocks (Hs: Hanseatic terrane) is detached through slab roll-back processes, they represent parts of South-Avalonia. Av, Avalonia; Ba, Baltica; Hs, Hanseatic; Ir, Iran; Kz, Kazakhstania; La, Laurentia, Lg, Ligerian arc system; Lr, Laurussia; NC, North-China; Sb, Siberia; SC, South-China; Tr, Tarim. Major rifts are shown in light orange, the red spot represents the Silurian Iranian hot spot. The cross-sections a, c and d, are located on the Eifelian reconstruction (B), they show how the collision of the Gondwana margin with an incoming intra-oceanic arc changed that margin from passive to active. For the other cross-sections see Fig. 7. This figure is in part derivative from the Neftex Geodynamic Earth Model. ( ) Neftex Petroleum Consultants Ltd. 2011. 
along the South Chinese portion of the margin. This can explain the presence of remnants of older oceans, either the Ordovician Rheic ocean (c. $460 \mathrm{Ma}$ and younger) or older fragments (c. $500 \mathrm{Ma}$, e.g. Arenas et al., 2007, 2009) related to the Qilian arc (part of proto-Hunia left behind on the Gondwana margin) and brought to the surface during the Rheic rifting, thus forming the toe of the Gondwanan Ordovician passive margin.

Recent re-dating of ophiolitic units shows that this eo-Variscan obduction event can be followed up to the Southern Carpathian domain (Plissart et al., 2012) with ages ranging from 409 to $380 \mathrm{Ma}$. However, ophiolitic remnants are not present everywhere along this eo-Variscan suture for different reasons, one of them is that this zone is colliding again with the blocks derived from Laurasia (Hanseatic terrane) from 360 to $340 \mathrm{Ma}$, then this collisional domain was affected by important strike slip events until $300 \mathrm{Ma}$. However, the eo-Variscan event affected all the blocks located along the border of Gondwana, and this can be seen also through the cessation of sedimentation in many basins at that time due to flexural bulging and/or ensuing slab detachment (see subsidence curves in von Raumer and Stampfli, 2008).

\section{Opening of Paleotethys}

We are departing here from our previous model (Stampfli et al., 2002) where Hunia was considered as the main ribbon-like microcontinent leaving Gondwana during the opening of Paleotethys in the Silurian. The Silurian accretion of Hunia to North China (Table 1) implies that this accretion took place when the Paleotethys was not yet opened. Thus, Hunia represents a first train of terranes leaving Gondwana more or less at the same time than Avalonia (during the Ordovician, see above). The second train of terranes leaving Gondwana in the Devonian has been called the Galatian superterrane (Stampfli et al., 2011).

In the late Ordovician, both western and eastern segments of the Rheic ocean made a single oceanic domain. North of Africa, the passive margin of Gondwana became an active margin again in the Devonian (see above). From the upper Ordovician to the Silurian, crustal extension is observed along the Gondwana margin through the sedimentary record, the subsidence patterns, the interruption of sedimentation and the intrusion of basic volcanic rocks at different places (von Raumer and Stampfli, 2008). New monazite age-data (Schulz and von Raumer, 2011) confirm an early Silurian thermal event for the Aiguilles Rouges area. Located along the S-Chinese (Gondwana) margin this area is the witness of the transform type eastern Rheic margin. The emplacement of 450 Ma gabbros at different places and the many early Silurian acidic volcanic rocks of the Noric Terrane are the signature of an extending crust in the Alpine domain; the older ones (450-420 Ma) are related to the eastern Rheic opening, the youngest (410-380 Ma) to the opening Paleotethys (von Raumer et al., 2013).

The opening of Paleotethys is well constrained along the Iranian segment of its southern margin (Bagheri and Stampfli, 2008), a late Ordovician-Silurian rift filled with very thick volcanic deposits, aborted in Early Devonian time, then a new rift opened. Red sandstones and evaporites of middle Devonian age, were followed by marine deposits in the Givetian, and final transgression of the rift shoulder took place in the Famennian. At the other end of the Paleotethys in Morrocco, the anti-Atlas region shows an evolution towards a passive margin setting already in the early Devonian (e.g. Ouanaimi and Lazreq, 2008), characterized by open marine sequences rich in ammonoids. This demonstrates the diachronous opening of Paleotethys from west to east.

A middle to late Devonian passive margin evolution can also be observed in Spain (Fig. 8) when considering the sedimentation from the West Asturian-Leonese and Cantabrian zones (García-Alcade, 2002; Fig. 8). Frasnian sequences are onlapping on large tilted blocks, a general transgression is represented by the Famennian over-lapping sequence, and slope to pelagic deposits (nodular limestones, ammonoids) are found in the Palentian domain. The distal part of this potential Iberic northern Paleotethys margin segment would have been subducted under the Pyrenees-Catalonia block in the Carboniferous, the rest of the region becoming a flexural basin filled-up by flysch deposit with marine incursions lasting until the end of the Carboniferous (an exception in the Variscan world). On the other side of the Iberic block, Frasnian volcanism is known in the Almaden region (García-Alcade, 2002). This scheme would confirm the opening of Paleotethys as a back-arc ocean. A late Devonian to Early Carboniferous arc is also known in the Bohemian massif (Lardeaux et al., 2012). Devonian subduction related granitoids are also found at the far end of the Galatian superterrane in the Sakarya block (Pt, in Fig. 8) of northern Turkey (Aysal et al., 2012).

\section{The Galatian superterrane accretion to Eurasia}

The Galatian superterrane was detached from Gondwana in segments, following the diachronous Ligerian arc collison with the Gondwana passive margin (eo-Variscan obduction/collisional event, c. $390 \mathrm{Ma}$, see above). It started from the west, north of N-Africa with the detachment of the Armorica s.l. segment around $400 \mathrm{Ma}$, then the Ibero-Ligerian fragment and the Intra-alpine, Mediterranean segment after (c. $380 \mathrm{Ma}$ ). Thermal subsidence of these blocks after their detachment from Gondwana is shown nearly everywhere by the development of pelagic sequences (stars on Fig. 8B) such as middle/late Devonian red nodular limestones, followed by Tournaisian/Visean black radiolarites (lydites), then by Tournaisian/Visean flysch with blocks, marking the onset of collision.

A triple junction was established around the Arabian promontory, corresponding to the three branches of Paleotethys. The Iranian seaway separated the Iranian-Afghan domain from South China, the Sulu-Dabie seaway separated South China from the intra-Alpine/ Mediterranean terranes, and the N-African seaway separated Gondwana from Armorica-Iberia.

These oceanic branches started out as back-arc basins that merged to give rise to the Devonian Paleotethys. During their drifting, the Iberian-Intra-Alpine segment passed behind the Armorican one. This imbrication was enhanced when Armorica collided with the Hanseatic arc detached from Laurussia in the late Devonian. Then the most eastern and external part of the Galatian terrane (the Mediterranean blocks s.l., comprising Italy, Greece, Turkey) by-passed the intra-Alpine blocks in a westward rotational movement following the overall anticlockwise rotation of Gondwana. The Paleotethys mid-ocean ridge had been subducted by now, as predicted by the model (Fig. 8C \& D), the mid-ocean ridge becoming perpendicular to the subduction zone. Then, a fair amount of coupling was possible between the rotating Gondwana plate and the active margin of Laurasia. Also, slab detachment in the Variscan collision zone allowed for a large amount of right lateral strike slip movements that even exaggerated the duplication of the former ribbon-like Galatian superterrane.

Along Laurasia an arc extended from Newfoundland up to the Caspian area, back-arc basins associated to it, are represented by the Rhenohercynian oceanic domain. It is characterized by important plutonism/volcanism that extended through most of the Devonian Period (e.g., Walliser, 1981; Ziegler, 1988; in the mid-German Crystalline High: Anthes and Reischmann, 2001; Reischmann and Anthes, 1996; in the South Portuguese volcanic-sedimentary complex (Pyrite Belt) of Late Famennian-Visean age, Thiéblemont et al., 1994; the Eastern Meseta, Hoepffner et al., 2005). Eastward, it is represented by the Paphlagonian pelagic domain (Stampfli and Kozur, 2006). This Hanseatic arc is made by terranes such as the South-Portuguese, Channel, East-Meseta and Mid-German Rise, and part of the Caucasus and Black-sea in the east. This arc north of the Rheic ocean could have been partly intraoceanic and was totally destroyed during the collision (Pereira et al., 2012a). The Hanseatic terranes/arc system, was 


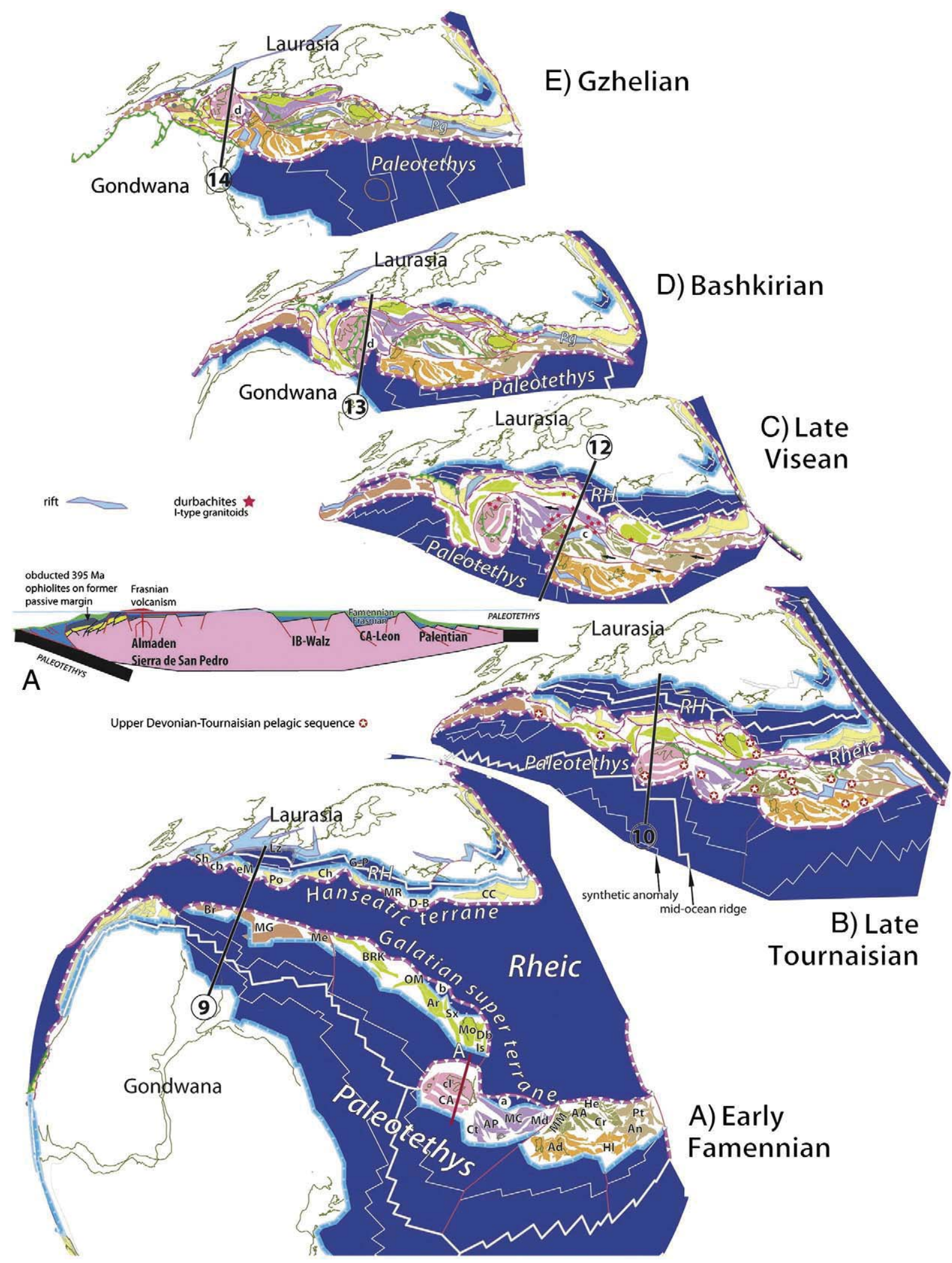

Fig. 8. Reconstructions of the Variscan domain for: A, Early Famennian, B, Late Tournaisian, C, Late Visean, D, Bashkirian and E, Gzhelian (modified from Stampfli et al., 2011); this model shows how the GDUs involved in the Variscan collision can be restored into a single ribbon-like superterrane before $370 \mathrm{Ma}$ (see Fig. 3 for legend). Along the Eurasian margin, the opening of the Rhenohercynian ocean (e.g., G-P, Harz-Giessen-Northern Phyllites zone) has detached the Hanseatic terrane from the mainland: Sh, Sehoul block; cb, coastal block; eM, eastern Meseta; Po, south Portuguese; Ch Channel; MR mid-German rise; D-B, Dacides-Bucovinian; CC, Caucasus. On A, Early Famennian reconstruction, a and b, show the possible location of back-arc basins opening along the leading edge of the Ligerian and Armorican terranes. On C, Late Visean reconstruction, c, corresponds to the Zone Houillère back-arc basin. On D, Bashkirian and E, Gzhelian reconstructions, d, corresponds to the Cantabrian-Ebro late Carboniferous marine embayment The terrane colour code corresponds to the one in Fig 9. $\mathrm{Pg}$, is the Paphlagonian sea-way, a potential successor of the Rhenohercynian ocean north of Turkey. The restored cross-section through the Iberic block is located on the A) Early Famennian reconstruction and discussed in the text. The grey line with dots is the Rheic suture in its preserved northern segment. This figure is in part derivative from the Neftex Geodynamic Earth Model. @ Neftex Petroleum Consultants Ltd. 2011. 
imbricated with fragments of the Armorican or Meguma terranes around the Iberian landmass. We roughly follow here the imbrication model of Martínez Catalán et al. (2007), where the amalgamated Armorican, Rhenohercynian terranes were indented by the Iberian promontory around 360-350 Ma. This imbrication produced a duplication of the sutures as can be seen on the late Tournaisian reconstruction (Fig. 8B), the main Rheic suture is located between the Hanseatic blocks and the Armorican ones, but also between Armorica and the Iberic, intra-Alpine blocks, although this southern suture would also comprise elements of Paleotethys. Continuing roll-back of the Rhenohercynian ocean northward allowed for more imbrication and even indenting of the Iberic block into the pre-existing terrane assembly until the end of the Carboniferous (Gutiérrez-Alonso et al., 2012), marked by a remnant marine trough between Iberia and the Pyrenean-Catalonian blocks. It is to be noted that at the beginning of the Iberian block translation, the subducting ocean was the Rheic (Fig. 6B), it was soon replaced by Paleotethys (Figs. 8 and 9A), and finally by the Rhenohercynian ocean (Fig. 8D \& E).

This indenting also created large oroclinal bending mainly in the Iberic-Morrocan domain (Figs. 8 and 9; Gutiérrez-Alonso et al., 2012;
Martínez Catalán, 2012), and large imbrication of pre-existing blocks in the Meseta domain of Morocco and Algeria (Hoepffner et al., 2005; Michard et al., 2008). In the Meseta domain, several phases of deformation have been recognized, marking 1) the collision of the MegumaGalatian terrane with the Hanseatic one in the Tournaisian, 2) the Visean deformation marking the collision of the amalgamated terranes with Laurasia, 3) the Late Carboniferous "major phase" marking the collision of Gondwana with Laurasia. This is accompanied by magmatism and volcanism, related to collision/subduction, and finally to slab detachment in the late Carboniferous, early Permian. Compression lasted until the early Permian. The final closing oceanic domain was Paleotethys; no ophiolitic remnants have been found, but this is generally the case with main oceans whose buoyancy is largely negative.

During the translation of the Galatian s.l. terranes from Gondwana to Laurasia, roll-back of the retreating Rheic ocean to the north may have triggered the opening of back-arc basins in the leading edge of the terranes. Such a back-arc basin has been recognized in the Vosges, Black-Forest (Skrzypek et al., 2012). These authors propose an opening related to the subduction of Paleotethys to the south, but as can be seen from Fig. 8 (A), such late Devonian back-arc basins would be

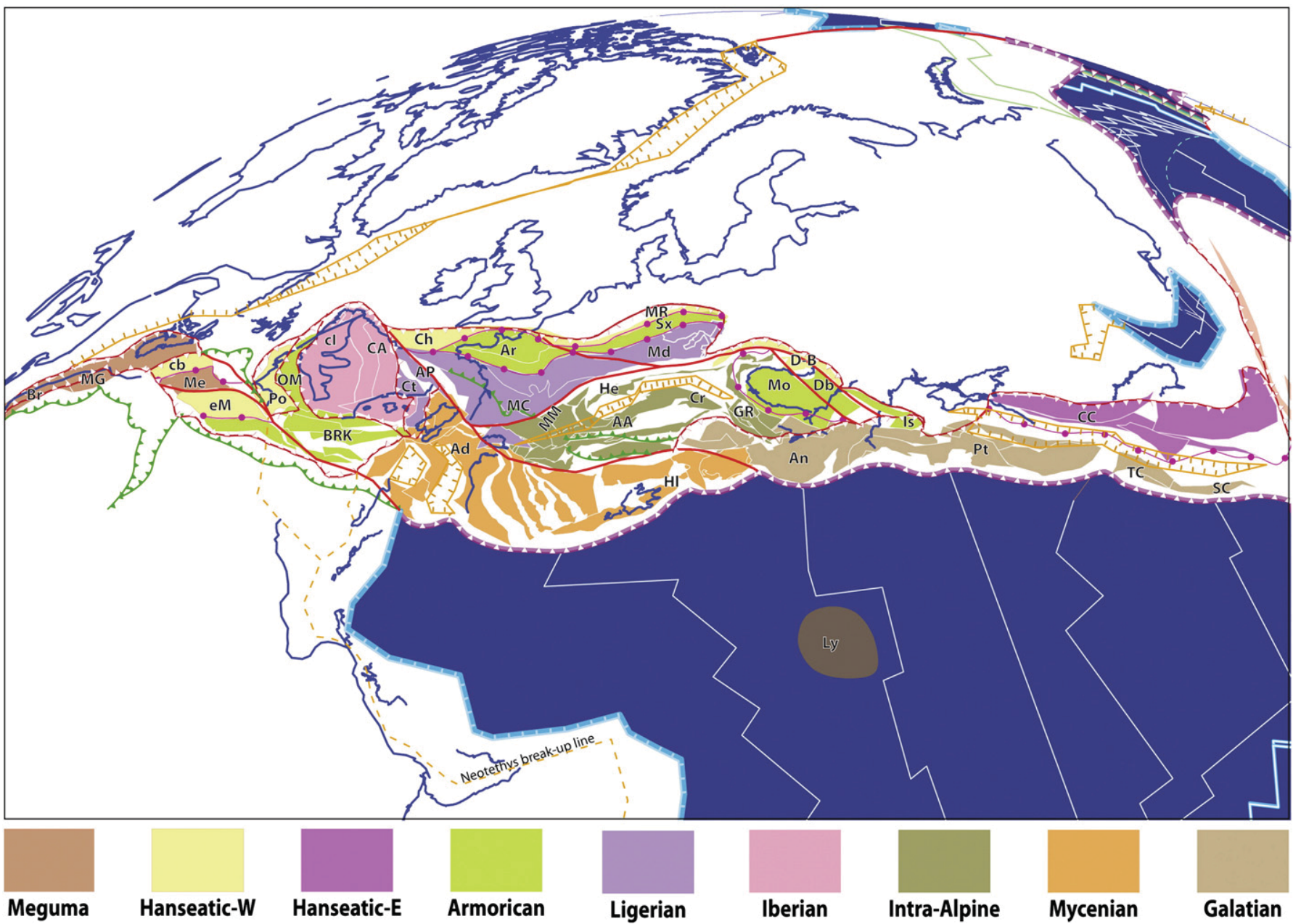

Fig. 9. Reconstruction for the Late Carboniferous (Gzhelian), modified from von Raumer et al., 2012 showing the division of the Galatian superterrane into sub-blocks during the amalgamation along the Eurasian margin. From north to south we find the Hanseatic terrane elements that were detached from Eurasia (in yellow in Europe and purplish east of the Black-Sea), they are strongly displaced and imbricated in Morocco with elements of the Meguma terrane. Next, we find the Armorican s.l. elements strongly indented by the Iberic block in the west. The red line with dots represents the potential location of the Rheic suture, duplicated during terrane transfer westward. South of the Armorica terrane are found the elements of the Ibero-Ligerian terrane of Fig. 6, divided now in two elements, the Iberic one and the Ligerian one. North of the former intra-Alpine terrane (now cut in three pieces, the Intra-Alpine s.str., the Galatian s.str., and the Mycenian terranes) the major strike slip zone in red is also a potential displaced Rheic suture. Eastward, we find the Galatian terrane s.str. (blocks composing mainly northern Turkey) whose southern elements were displaced westward to form the Mediterranean Variscan blocks named Mycenian terrane (Hellenidic, Dinaridic and Italic blocks). The Triassic Paleotethys suture is found south of these two last terranes, in which remnants of seamounts are found (e.g. Ly, Carboniferous seamount of the Lycian nappes, Moix et al., 2008), but an older (Carboniferous) Paleotethys suture should also be present all around the African promontory (e.g. Sicily, Morocco, see text). The lines with triangles (green or red) show potentially still active thrusting fronts at that time. Abbreviations for GDUs are on Figs. 3 and 8; TC, Transcaucasian, SC, South Caspian. This figure is in part derivative from the Neftex Geodynamic Earth Model. @ Neftex Petroleum Consultants Ltd. 2011. 
related to the subducting Rheic ocean located north of these regions. The Visean inversion recognized in the Vosges, would correspond to the collision of the amalgamated Hanseatic and detached Ligerian arcs, with the Ligerian terrane. However, in view of the inferred obliquity of the collision, it is not sure where exactly the back-arc basin was located. Another back-arc relic is known in the Armorica terrane in Brittany (Barboni, 2011). So, the back-arc may have been formerly in front of the Armorica terrane only, and during translation, the Ligerian terrane was juxtaposed to the collided arcs. The presence of these basins in front of the major blocks complicates establishing the polarity of subduction and the nature of block juxtapositions. Such a scenario could explain the varying vergence of the nappe structure in the chain.

The large Zone Houillère rift in the western Alps (Briançonnais, e.g. Cortesogno et al., 1984) and its Carboniferous calc-alkaline volcanism and associated Versoyen mafic complex (dated at $337 \mathrm{Ma}$, Mugnier et al., 2008) represent a potential back-arc too, again related to the subducting ocean to the north, rather than to the south, here it would have been the Rhenohercynian ocean, after the closure of the Rheic (Fig. 8D). The Paphlagonian basin north of Turkey contains Carboniferous radiolarites, late Permian pelagic deposit are also recorded (Stampfli and Kozur, 2006). It is difficult to envisage how the basin stayed opened during the main Variscan shortening phase, and as the stratigraphic record is known only from blocks it could be envisaged that the late Permian basin was a Paleotethyan back-arc, whereas the older sequences correspond to an eastern equivalent of the Rhenohercynian ocean.

As can be seen in Fig. 7 (350-340 Ma), the arc-arc collision was followed by lithospheric delamination due to the disapearing Rheic ocean. This process is regarded as the source of the numerous durbachites/I-type granitoids (stars on Fig. 8C) emplaced at that time in the nascent orogen (von Raumer et al., 2012, 2013). The arc-arc collision was followed by subduction reversals on both sides of the arc-arc collage, which led to subduction of the Paleotethys toward the north, and the Rhenohercynian ocean toward the south. The latter did not last very long and a late Carboniferous slab detachment can be expected along the northern suture zone. It can be placed at the transition from marine to lacustrine deposits around the Wales-Brabant high (flexural bulge) at the beginning of the Westphalian (Late Bashkirian, c. 315-310 Ma, Waters and Davies, 2006). In the Paleotethys, slab window due to the mid-ocean ridge subduction took place between 340 and $320 \mathrm{Ma}$. These numerous and repeated lithospheric events where the asthenosphere/lithosphere boundary is rapidly changing, could explain the large number of migmatite formation and granite intrusion at that time.

Terranes located to the south of the Variscan orogenic collage (mainly the Mycenian terrane, Figs. 8 \& 9) were transported westward after the subduction of the Paleotethyan mid-ocean ridge (see above); a situation that triggered re-attachment of these blocks to the Gondwanan plate (Fig. 7, 330-320 Ma), which was rotating anticlockwise at that time with regards to Laurasia. This rotation is due to the fact that collision already took place between North and South America, pinning the plate in that region, and to the strong northward slab pull of Paleotethys. This rotation is well expressed in the APWP of Fig. 5, with a change in direction marking the formation of Pangea. Finally, in the Late Carboniferous, Gondwana collided with the terranes accreted earlier to Laurasia, causing the final Variscan tectonic events from Florida to Spain.

\section{Post-Variscan extensional events}

As discussed above, a marine embayment remained open between the Iberic and Pyrenean block until the late Carboniferous (Fig. 8, D and E), which was filled up by flysch deposits (Cantabrian basin, and Ebro region, Colmenero et al., 2002). Upper Carboniferous marine sequences are also known from the Tuscan domain in Italy. In both areas these are followed by Permo-Triassic continental deposits, but to the south and eastward, pelagic early Permian series are known in Sicily, Greece and Turkey, where subduction/accretion continued along the northern margin of Paleotethys (Stampfli and Borel, 2004; Stampfli et al., 2003). From Greece to Iran, this active Paleotethys margin generated a series of oceanic back-arc basins during the Triassic.

The Late Carboniferous was the time of over-thickening of the Variscan lithosphere due to imbrication of the different blocks (Fig. 8) and also to slab detachment of the intervening oceans (Rhenohercynian, Rheic, Paleotethys; Fig. 7). Late Carboniferous to early Permian volcanism and magmatism can be related to these events; however, along the Paleotethyan margin, magmatism of that age can be related to continuing northward subduction and related extension in the upper plate. Effectively, the collisional system ended eastward, in a very similar manner as the Himalayan-Tibetan collision zone ends eastward towards the Pacific (Molnar and Tapponnier, 1975). The amalgamation of the blocks was rapidly followed by lithospheric collapse above the retreating Paleotethys slab from Sicily to the Middle-East. In the Pelagonian cordillera for example, granitic emplacement is dated between 325-300 Ma, and exhumation ages are early Permian (295-280 Ma; Vavassis et al., 2000), showing an immediate change to unroofing/extension in the upper plate (Laurasia) following slab retreat after the closure of the oceanic domains north of the chain. Similar observations can be made in many places in the southern Variscan belt. In the Ligurian Briançonnais (western Alps, e.g. Dallagiovanna et al., 2009) a change from early Permian calc-alkaline to middle Permian K-alkaline rhyolites is thought to date the transition from collision to delamination of the continental lithosphere. Many other places in the Alps show voluminous magmatism of Permo-Triassic age (Spalla et al., 2012), usually following post-collisional late Carboniferous granitic emplacements (e.g. von Raumer et al., 2009).

Permian rifting is actually affecting the whole Variscan chain (from Germany to Greece and from Spain to the Caucasus; e.g. Ziegler and Stampfli, 2001 and references therein), quickly re-equilibrating the crust and lithospheric mantle to their present-day average thicknesses, and developing a giant basin and range zone $(1500 \times 3000 \mathrm{~km})$. The sea invaded some Permian grabens (Carnic Alps domain and Greece, De Bono et al., 2002), whereas the arc/fore-arc domain in the south remained under deep water from the Early Permian to the middle Triassic, with known pelagic series in Sicily, Greece and Turkey (Stampfli and Borel, 2004; Stampfli et al., 2003). In Turkey and Iran, accretion of Carboniferous and Permian Paleotethyan seamounts has also been demonstrated at that time (Bagheri and Stampfli, 2008; Moix et al., 2008; Okay, 2000, and references therein) and allows to trace the Paleotethys suture despite of the lack of ophiolites in most places and the subsequent duplication of the suture (Stampfli and Borel, 2004).

In the Triassic, extension in the upper plate led to the opening of oceanic marginal basins (Stampfli and Kozur, 2006), younging southward (Scythian to Anisian in Meliata and Küre basins, Ladinian in the Maliac basin and Carnian in the Pindos basin). These openings were stopped in the Carnian through the collision of the Eurasian arc with the Cimmerian blocks detached from Gondwana (eo-Cimmerian phase, e.g. Śengör, 1979). The Late Triassic Paleotethyan slab detachment from Sicily to China, changed considerably the forces at the Pangea plate limits and triggered its break-up, well shown by the development of late Triassic rifts in the future Atlantic and Caribbean regions (see below).

\section{The global Pangea}

Large ribbon-like continental fragments left Laurentia to be accreted until the Triassic to South-America, Australia and Antarctica (the famous SAMFRAU geosyncline of Du Toit, 1937) as shown in Fig. 10. The 


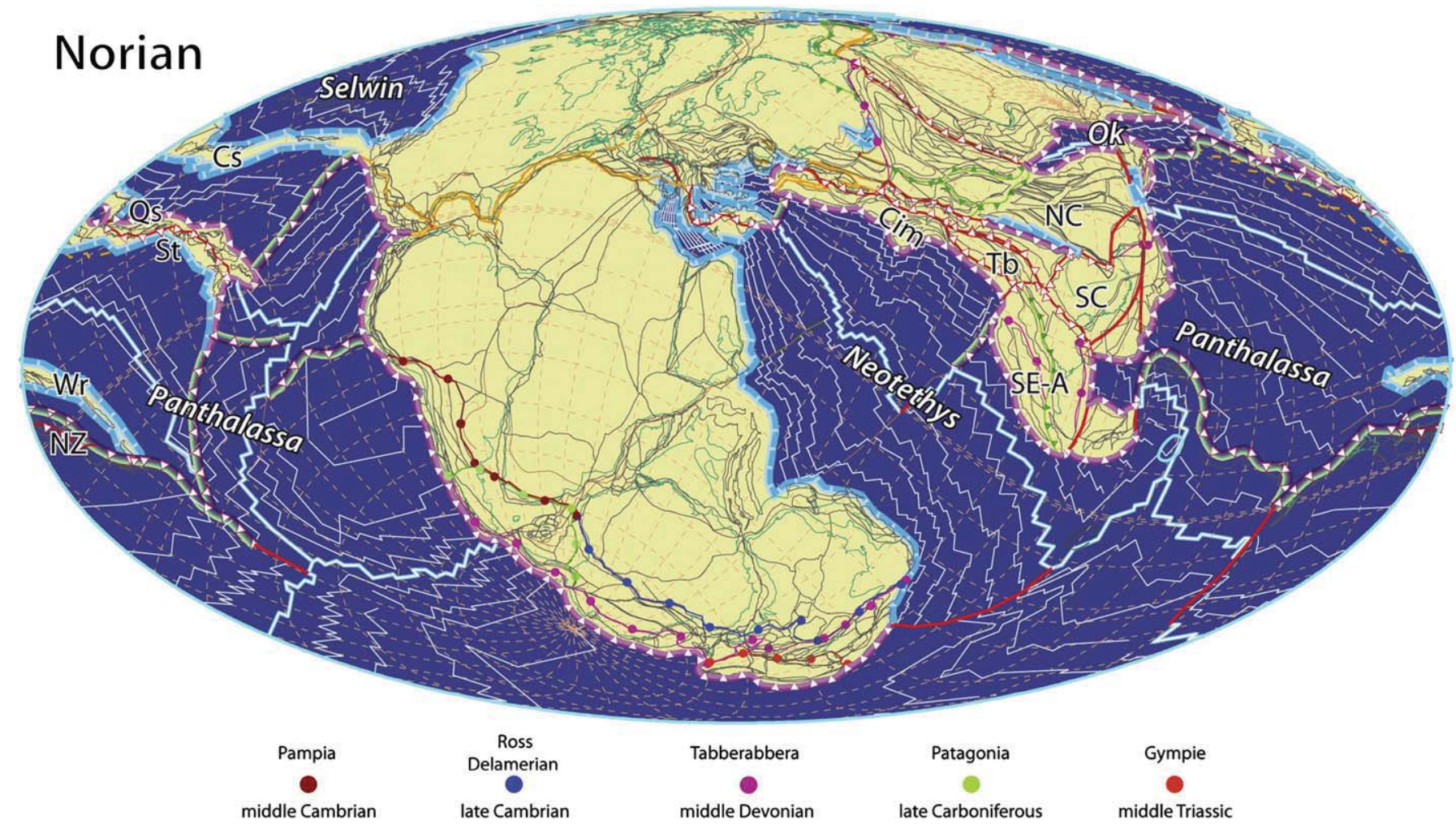

Fig. 10. Mollweide projection of the world in the Norian (modified from Chablais et al., 2011; see also: Bandini et al., 2011; Flores, 2009; Vérard et al., 2012a). Wrangelia and Stikinia formed a single terrane derived from the Austalian side of Gondwana in the late Carboniferous. During their transfer to Laurentia, Wrangelia was abandoned and is soon to be colliding with an intra-oceanic arc comprising blocks now found in New-Zealand. Wrangelia comprised also large volcanic plateaus (Peninsular and Kamutsen terranes). The disappearing oceanic plate between Stikinia and Quesnellia was the Permo-Carboniferous Panthalassa or Cache Creek ocean (e.g. Johnston and Borel, 2007 and references therein). At any time, Panthalassa was made of several mainly oceanic plates, separated by mid-ocean ridges and intra-oceanic subduction zones. Arc-arc collisions were common, as it is the case on this figure between Stikinia and Quesnellia. Cim, Cimmerian terrane; Cs, Cassiar; NC, North-China; NZ, New-Zealand; Ok, Okhotsk; Qs, Quesnellia; SE-A, South-East Asia; SC, South-China; St, Stikinia; Tb, Tibetan blocks (not South-Lhassa which is in the Cimmerian blocks); Wr Wrangelia. The main sutures on the Panthalassa side of Gondwana are indicated (see text). This figure is in part derivative from the Neftex Geodynamic Earth Model. @ Neftex Petroleum Consultants Ltd. 2011.

oldest sutures (Pampia, Ross, Delamerian) date from the amalgamation of Gondwana; large continental fragment were added to Australia and Antarctica in the Late Cambrian-Ordovician times, at the same time micro-continents and arcs were accreted to South-America (Pampia event, Ramos et al., 2010). The Tabberabbera suture corresponds to the accretion of a large intra Panthalassa arc (Yass arc complex) during the Devonian. The Patagonia one corresponds to the opening and closing of a Carboniferous back-arc ocean. The Gympie suture is related to the last accretion of a large continental ribbon continent to Australia. This set of terranes was most likely derived from North-America, and some were abandoned during the long translation of the arc up to the Australian regions (Vérard and Stampfli, in press, submitted for publication). Some large blocks/ribbons were also re-detached from the Australian Panthalassa margin during the late Carboniferous, to form the future Wrangelia-Stikinia terrane, crossing the entire Panthalassa (we adopt here the point of view of Johnston and Borel, 2007, that we tested in terms of velocities and paleobiogeography, but many other options exist also). Stikinia collided with terranes detached during the Devonian (Cassiar) and the Permian (Quesnellia) from the American Pacific active margin, the detached terranes and the exotic ones will be re-accreted to North America from the Triassic to the Cretaceous (Flores, 2009). The suture between Stikinia and Quesnellia contains numerous remnants of mainly Permian seamounts with typical Tethyan microfauna, showing that Stikinia did cross the tropical zone of Panthalasa during the Permian. The abandoned Wrangelia terrane is also associated to upper Triassic carbonates that show it was located in the intertropical zone at that time (e.g. Jones et al., 1977; Fig. 9). Triassic seamounts with Tethyan fauna are also known from Japan, we traced these through our plate model to find their former location in the tropical Triassic Panthalassa (Chablais et al., 2011).
The other major blocks that participated to the build-up of Pangea were Siberia, Kazakhstan and the Tarim, North Chinese blocks, forming the pendant of the Variscan orogen in Asia, the Altaids. A new model of this complex orogen was developed at Lausanne (Wilhem, 2010; Wilhem et al., 2012), incorporating the latest data from Chinese and Russian colleagues, mainly regarding new ages of metamorphism and magmatism. We followed this model herein. Multiple peri-Siberian accretion-collision events took place before the end of the Early Paleozoic. The MongolOkhotsk Ocean opened within this new accreted continent in the Early-Middle Paleozoic. The Kazakhstan continental block was formed in the Early Silurian in Eastern Gondwana by the accretion-collision of several ribbon-microcontinents and island-arctype terranes. Most Kazakhstan microcontinents originated in Gondwana (Fig. 1, the part of Kazakhstan in light blue) from which they were detached in the Vendian to middle Cambrian to collide with the Indochina-Cathay arc/terranes complex (the ones in light green in Fig. 1) and continued their course westward by-passing the Chinese blocks (Wilhem et al., 2012, Fig. 4E and F). Kazakhstania was finally created from the Arenigian to the Early Silurian. The complete Kazakhstania moved westward toward Siberia and Tarim, North-China in the Middle-Late Paleozoic.

From the mid-Paleozoic, Siberia, Tarim/North-China and Kazakhstania began to mutually interact (Fig. 6). The new plate tectonic arrangements led to oroclinal bending and large-scale rotation of Kazakhstania during the Carboniferous; the main terminal sutures of the Altaids are Permo-Triassic. Following the completion of the Altaids, only the Mongol-Okhotsk ocean remained opened until the Jurassic-Cretaceous (Fig. 10). Siberia was finally welded to Baltica not before the end of the Triassic in the Arctic regions (Fig. 11). 


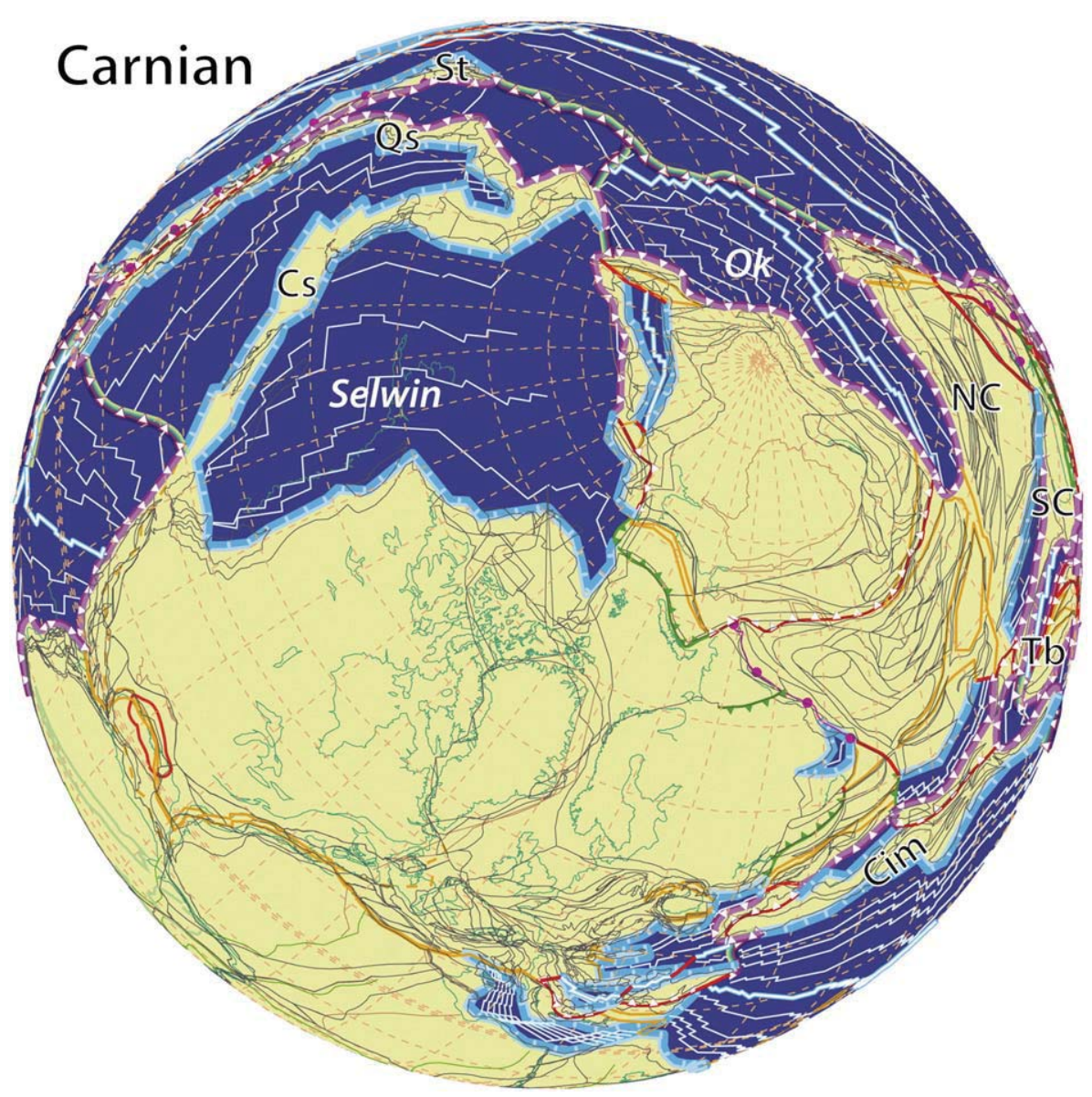

Fig. 11. North pole view of the world in the late Carnian. On this figure one can assess the importance of the Laurasian part of Pangea, to which Siberia has been finally assembled. The Cimmerian, Tibetan and South-Chinese terranes are in the process of final amalgamation that can be placed in the Norian. The Selwin (Saybian) ocean can be seen as an intra Pangea ocean has it is not spreading. Its opening was mainly in the Devonian and its width can be determined through the distribution of Late Paleozoic carbonate in the Cassiar terrane and also kinematic constraints regarding its closure that took place in the Cretaceous mainly (see Bandini et al., 2011; Johnston, 2008). A large plume (red line) is shown under the opening Gulf of Mexico rift system. For legend see Fig. 10. This figure is in part derivative from the Neftex Geodynamic Earth Model. @ Neftex Petroleum Consultants Ltd. 2011.

The final welding of Siberia on one side and of the Cimmerian, Tibetan and South-Chinese blocks on the other, to Laurasia can be placed in the Late Triassic (e.g. Ferrari et al., 2008; Wilhem, 2010) and resulted in a reorganization of the forces at the Pangean plate boundaries, triggering its break-up. In Figs. 10 and 11 one can see that a first system of rift initiated along the Variscan suture from central America through the Gulf of Mexico (Ouachita suture) and central Atlantic region up to North-Africa, along the future Atlas system. The Gulf of Mexico and Atlas rift systems aborted and were replaced by the proto-Caribbean seaway (Bandini et al., 2011) and the Alpine Tethys (Stampfli and Hochard, 2009) during early Jurassic times, which marks the real break-up of Pangea.

\section{Conclusions}

Amalgamation of continents can be a simple event when dealing with large continental blocks. However, most of the time, smaller terranes are involved in the suturing of disappearing oceans. The Variscan or Altaids domains are good examples of this juxtaposition of terranes of different origins. The final structural framework of these mountain belts can be misleading when looking at the geodynamic relationship between juxtaposed blocks, and only a thorough analysis of the geodynamic scenarios of each block can finally allow determining the exotic/local nature of the terranes. In the Variscan domain, "cylindricity" of the chain never really existed, excepted for the eo-Variscan event that took place along the Gondwana margin. After that, duplication of the original framework took place at many scales until final juxtaposition of unrelated fragments. Oceanic sutures were duplicated and were also the site of continental scale strike-slip faults, but many of these large faults are not sutures. So, defining the original provenance of the Variscan blocks at the Gondwana margin remains the major tool to unravel the possible scenario of their wandering between Gondwana and Laurasia.

The making of Pangea had to start first with the amalgamation of Gondwana around 520-510 Ma, producing an already large landmass. Then, in the Ordovician, series of ribbon continents left Gondwana to be accreted to the newly formed Laurussia or to North-China/Tarim. On the southern side of Gondwana, accretion of terranes also continued from the Paleozoic to the Triassic, mainly along the Antarctica-Australia margins, most of these terranes originated from southern Laurentia. Finally, in the late Carboniferous, Gondwana started to collide with Laurussia. Pangea was born at that time (c. $300 \mathrm{Ma}$ ) and lasted until the end of the Triassic (200 Ma). In the meantime, large continental masses were added to it, such as Siberia-Kazakhstania, North-China/ Tarim, and finally South-China/SE-Asia and ribbon continents such as the Cimmerian and Tibetan blocks that originated from Gondwana and whose drifting finally closed the Paleotethys. By that time, nearly all continental blocks on Earth were parts of Pangea.

This final Carnian-Norian accretion to Laurasia (eo-Cimmerian event) changed the forces at the plate boundaries, mainly when subduction started north of Neotethys under the accreted Cimmerian blocks and when also subduction progradation jumped north of the 
Quesnellia arc after its collision with Stikinia. These two synchronous events produced diverging forces acting mainly on the Laurasian part of Pangea, and break-up took place in the over thickened crust along the Variscan suture, producing series of continental rifts filled by Late Triassic sediments, from the Gulf of Mexico to the Algerian Atlas. Final break-up took place during the opening of the proto-Caribbean/ central Atlantic/Alpine-Tethys oceanic system in the early Jurassic (Stampfli and Hochard, 2009).

\section{Acknowledgements}

The global reconstruction model and database elaborated at the Lausanne University using plate tectonic and synthetic isochrone principles was of a great help in constraining geometries and plate velocities. These factors are fundamental when considering the wandering of a large plate such as Gondwana. But this would be useless without the repeated efforts of several generations of field geologists that gathered key information from the whole world, their work is strongly acknowledged here. We are grateful to the University of Lausanne, the Swiss National Science Foundation, Shell and Neftex, for financial support. The work was carried out as part of the research program of the University of Lausanne on the "Stampfli geodynamic model", which is now owned by Neftex Petroleum Consultants Ltd. and attached to the "Neftex Earth Model". We are grateful to Neftex for allowing us to present in this publication some details from the geodynamic model obtained prior to 28th February 2010.

We are grateful to Bernhard Schulz and Cees van Staal who made a thorough review of this manuscript.

\section{References}

Amante, C., Eakins, B., 2009. Etopo1 arc-minute global relief model: procedures, data sources and analysis. NOAA Technical Memorandum Nesdis NGDC-24, Boulder CO. (19 pp.; available at http://ngdc.noaa.gov/mgg/global/global.,html).

Anthes, G., Reischmann, T., 2001. Timing of granitoid magmatism in the eastern midGerman crystalline rise. Journal of Geodynamics 31, 119-143.

Arenas, R., Martínez Catalán, J.R., Sánchez Martínez, S., Fernández-Suárez, J., Andonaegui, P., Pearce, J.A., Corfu, F., 2007. The Vila de Cruces Ophiolite: a remnant of the early Rheic ocean in the Variscan suture of Galicia (northwest Iberian Massif). Journal of Geology 115, 129-148.

Arenas, R., Sánchez Martínez, S., Castiñeiras, P., Jeffries, T.E., Díez Fernández, R Andonaegui, P., 2009. The basal tectonic mélange of the Cabo Ortegal Complex (NW Iberian Massif): a key unit in the suture of Pangea. - La mélange tectónica basal del Complejo de Cabo Ortegal (NW del Macizo Ibérico): una unidad clave en la sutura de Pangea. Journal of Iberian Geology 35 (2), 85-125.

Aysal, N., Ustaömer, N., Öngen, S., Keskin, M., Köksal, S., Peytcheva, I., Fanning, M., 2012 Origin of the Early-Middle Devonian magmatism in the Sakarya Zone, NW Turkey: geochronology, geochemistry and isotope systematics. Journal of Asian Earth Sciences 45, 201-222.

Bachtadze, V. Briden, J 1991. Paleomagnetic constraints on the position of Gondwana during Ordovician to Devonian times. In: McKerrow, W.S., Scotese, C.R. (Eds.), Palaeozoic Palaeogeography and Biogeography: Geological Society Memoirs, 12, pp. 43-48.

Bagheri, S., Stampfli, G.M., 2008. The Anarak, Jandaq and Posht-e-Badam metamorphic complexes in central Iran: new geological data, relationships and tectonic implications. Tectonophysics 451, 123-155.

Balintoni, I., Balica, C., 2013. Carpathian peri-Gondwanan terranes in the East Carpathians (Romania):A testimony of an Ordovician, North-African orogeny. Gondwana Reasearch 23 (3), 1053-1070.

Bandeira, J., McGee, B., Nogueira, A., Collins, A., Trindade, R., 2012. Sedimentological and provenance response to Cambrian closure of the Clymene Ocean: the upper Alto Paraguai Group, Paraguay Belt, Brazil. Gondwana Research 21, 323-340.

Bandini, A.N., Baumgartner, P.O., Flores, K., Dumitrica, P., Hochard, C., Stampfli, G.M., Jackett, S.J., 2011. Aalenian to Cenomanian Radiolaria of the Bermeja Complex (Puerto Rico) and Pacific origin of radiolarites on the Caribbean Plate. Swiss Journal of Geosciences 104, 367-408.

Barboni, M., 2011. Construction mechanisms and thermal evolution of upper crustal intrusions: the Saint-Jean-Du Doigt bimodal intrusion (Brittany, France) [Ph.D. thesis]: Université of Lausanne, $286 \mathrm{pp}$.

Bian, Q.-T., Gao, S., Li, D., Ye, Z., Chang, C.-F., Luo, X., 2001. A study of the KunlunQilian-Qinling suture system. Acta Geologica Sinica 75, 364-374.

Bian, Q.-T., Li, D.-H., Pospelov, I., Yin, L.-M., Li, H.-S., Zhao, D.-S., Chang, C.-F., et al., 2004 Age, geochemistry and tectonic setting of Buqingshan ophiolites, North QinghaiTibet Plateau. China Journal Asian Earth Sciences 23, 577-596.

Boger, S., 2011. Antarctica - before and after Gondwana. Gondwana Research 19, 335-371.

Bonev, N., Stampfli, G.M., 2011. Alpine tectonic evolution of a Jurassic subductionaccretionary complex: deformation, kinematics and $40 \mathrm{Ar} / 39 \mathrm{Ar}$ age constraints on the Mesozoic low-grade schists of the Circum-Rhodope Belt in the eastern Rhodope-Thrace region, Bulgaria-Greece. Journal of Geodynamics 52, 143-167.

Boulin, J., 1988. Hercynian and Eocimmerian events in Afghanistan and adjoining regions. Tectonophysics 148 (3-4), 253-278.

Brookfield, M.E., 2000. Geological development and Phanerozoic crustal accretion in the western segment of the southern Tien Shan (Kyrgyzstan, Uzbekistan and Tajikistan). Tectonophysics 328 (1-2), 1-14.

Buchwaldt, R., Tucker, R., Dymek, R., 2003. Geothermobarometry and U-Pb geochronology of metapelitic granulites and politic migmatites from the Lokoho region, northern Madagascar. American Mineralogist 88, 1753-1768.

Caby, R., 2003. Terrane assembly and geodynamic evolution of central-western Hoggar: a synthesis. Journal of African Earth Sciences 37, 133-159.

Chablais, J., Martini, R., Kobayashi, F., Stampfli, G.M., 2011. Upper Triassic foraminifers from Japanese Panthalassan mid-oceanic carbonate buildups (Sambosan Accretionary Complex): palaeobiogeographic implications. Micropaleontology 57 (2), 93-124.

Collins, A., Kröner, A., Fitzsimons, I., Razakamanana, T., 2003. Detrital footprint of the Mozambique ocean: $\mathrm{U} / \mathrm{Pb}$ SHRIMP and $\mathrm{Pb}$ evaporation zircon geochronology of metasedimentary gneisses in Eastern Madagascar. Tectonophysics 375, 77-99.

Colmenero, J.R., Fernández, L.P., Moreno, C., Bahamonde, J.R. (coord.), 2002. Carboniferous. In: Geology of Spain, Gibbons W. and Moreno, T. (Eds.). The Geological Society of London, 93-116.

Cortesogno, L., Gianotti, R., Vannuci, R., Vanossi, M., 1984. Le volcanisme permocarbonifère du Briançonnais ligure (Alpes marit mes) dans le cadre des phases tardives de l'orogenèse hercynienne. Sciences Géologiques Bulletin, Strasbourg $37,37-50$

Dallagiovanna, G., Gaggero, L., Maino, M., Seno, S., Tiepolo, M., 2009. U-Pb zircon ages for post-Variscan volcanism in the Ligurian Alps(Northern Italy). Journal of the Geological Society 166, 101-114.

Dantas, E., Souza de Alvarenga, C., Santos, R., Pimentel, M., 2009. Using Nd isotopes to understand the provenance of sedimentary rocks from a continental margin to a foreland basin in the Neoproterozoic Paraguay Belt, Central Brazil. Precambrian Research 170, 1-12.

DaSilva, L., Pedrosa-Soares, A., Teixeira, L., Armstrong, R., 2008. Tonian rift-related, A-type continental plutonism in the Araçuaí Orogen, eastern Brazil: new evidence for the breakup stage of the São Francisco-Congo Paleocontinent. Gondwana Research 13, 527-537.

De Bono, A., Vavassis, I., Stampfli, G.M., Bartolini, A.C., 2002. Late Paleozoic-Mesozoic evolution of the Pelagonian internal margin (Greece). Eclogae Geologicae Helvetiae 94 (3), 289-311.

DeAraújo, C., Pinéo, T., Caby, R., Costa, F., Cavalcante, J., Vasconcelos, A., Rodrigues, J. 2010. Provenance of the Novo Oriente Group, southwestern Ceará Central Domain, Borborema Province (NE-Brazil): a dismembered segment of a magma-poor passive margin or a restricted rift-related basin? Gondwana Research 18, 497-513.

DeWaele, B., Horstwood, M., Pitfield, P., Thomas, R., Key, R., Rabarimana, M., Rafahatelo, J-M., Ralison, V., Randriamananjara, T. 2009. The architecture of the "Betsimisaraka Suture Zone": a record of oceanic arcs and associated metasedimentary successions between the "Indian" and "African" parts of Madagascar. International Conference on Island Arc, Continent Collisions, The Macquarie Arc Conference, Orange, Australia, April 2009, pp. 56-57.

Dos Santos, T., Fetter, A., Neto, J., 2008. Comparisons between the northwestern Borborema Province, NE Brazil, and the southwestern Pharusian Dahomey Belt, SW Cetnral Africa. In: Pankhurst, R., Trouw, R., Brito Neves, B., De Wit, M. (Eds.), West Gondwana Pre-Cenozoic correlations across the South Atlantic Region: Geological Society, London, Special Publications, 294, pp. 101-119.

du Toit, A.L., 1937. Our Wandering Continents; an Hypothesis of Continental Drifting. Oliver and Boyd, London, UK.

Faure, M., Lin, W., Le Breton, N., 2001. Where is the North China-South China block boundary in eastern China? Geology 29 (2), 119-122.

Ferrari, O.M., Hochard, C., Stampfli, G.M., 2008. An alternative plate tectonic model for the Palaeozoic-Early Mesozoic Palaeotethyan evolution of Southeast Asia (Northern Thailand-Burma). Tectonophysics 451, 346-365.

Fitzsimons, I., 2003. Proterozoic basement provinces of southern and south-western Australia, and their correlation with Antarctica. In: Yoshida, M., Windley, B. Dasgupta, S. (Eds.), Proterozoic East Gondwana: Supercontinent Assembly and Breakup: Geological Society, London, Special Publications, 206, pp. 93-130.

Flores, K., 2009. Mesozoic Oceanic Terranes of southern Central America - geology, geochemistry and geodynamics. PhD Thesis, University of Lausanne, Switzerland, 290 pp. Available from: http://www.unil.ch/serval.

Franke, W., 2000. The mid european segment of the Variscides: tectono-stratigraphic units, terrane boundaries and plate tectonic evolution. In: Franke, W., Haak, V., Oncken, O., Tanner, D. (Eds.), Orogenic processes: quantification and modelling in the Variscan belt: Geological Society of London Special Publication, 179, pp. 35-62.

Gaetani, M., 1997. The Karakorum Block in Central Asia, from Ordovician to Cretaceous. Sedimentary Geology 109 (3-4), 339-359.

García-Alcade, J.L. coord., 2002. Devonian. In: Geology of Spain, Gibbons W., Moreno, T. (Eds.). The Geological Society of London, 67-92.

Géologie de la France, 2012. Length scales, times scales and relative contribution of Variscan orogenic events to formation of European crust. Special meeting of French and Italian Geological Societies, Sassari (229 pp.).

Ghienne, J.-F., 2011. The Late Ordovician glacial record: state of the art. In: Gutiérrez-Marco, J.C., Rábano, I., García-Bellido, D. (Eds.), The Ordovician of the World. Cuadernos del Museo Geominero 14. Instituto Geológico y Minero de España, Madrid, pp. 13-19.

Gray, D., Foster, D., Goscombe, B., Passchier, C., Trouw, R., 2006. ${ }^{40} \mathrm{Ar} /{ }^{39} \mathrm{Ar}$ thermochronology of the Pan-African Damara Orogen, Namibia, with implications for tectonothermal and geodynamic evolution. Precambrian Research 150, 49-72. 
Gray, D., Foster, D., Meert, J., Goscombe, B., Armstrong, R., Trouw, R., Passchier, C., 2008. A Damara orogen perspective on the assembly of southwestern Gondwana. In: Pankhurst, R., Trouw, R., Brito Neves, B., De Wit, M. (Eds.), West Gondwana Pre-Cenozoic Correlations Across the South Atlantic Region, Geological Society, London, Special Publications, 294, pp. 257-278.

Gutiérrez-Alonso, G., Fernández-Suárez, J., Gutiérrez Marco, J.C., Corfu, F., Murphy, J.B., Suárez, M., 2007. U-Pb depositional age for the upper Barrios Formation (Armorican Quartzite facies) in the Cantabrian Zone of Iberia: implications for stratigraphic correlation and paleogeography. In: Linnemann, U., Nance, R.D., Zulauf, G., Kraft, P. (Eds.), The Geology of Peri-Gondwana: The Avalonian-Cadomian Belt: Adjoining Cratons and the Rheic Ocean: Geological Society of America, Special Paper, 423, pp. 287-296.

Gutiérrez-Alonso, G. Pastor-Galán, D. Fernández-Suárez, J., Jeffries, T. Collins, A.S Johnston, S.T., Weil, A.B., 2012. Late-Post Variscan buckling of the Ibero-Armorican arc: the lithospheric scale tale. Length scales, times scales and relative contribution of Variscan orogenic events to formation of European crust, Special meeting of French and Italian Geological Societies, Sassari: Géologie de la France, 1, pp. 123-124.

Gutiérrez-Marco, J.C., Rábano, I., García-Bellido, D. (Eds.), 2011. Ordovician of the World. Cuadernos del Museo Geominero 14. Instituto Geológico y Minero de España, Madrid (682 pp.)

Hacker, B.R., Ratschbacher, L., Liou, J.G., 2004. Subduction, collision and exhumation in the ultrahigh-pressure Qinling-Dabie orogen. Geological Society, London, Special Publications 226 (1), 157-175.

Hamdi, B., Brasier, M.D., Zhiwen, Jiang, 1989. Earliest skeletal fossils from PrecambrianCambrian boundary strata, Elburz Mountains, Iran. Geological Magazine 126 (03), 283-289.

Hanson, R., 2003. Proterozoic geochronology and tectonic evolution of southern Africa. In: Yoshida, M., Windley, B, Dasgupta, S. (Eds.), Proterozoic East Gondwana: Supercontinent Assembly and Breakup: Geological Society, London, Special Publications, 206, pp. 427-463.

Harley, S., 2003. Archaean-Cambrian crustal development of East Antarctica: Metamorphic characteristics and tectonic implications. In: Yoshida, M., Windley, B. Dasgupta, S. (Eds.), Proterozoic East Gondwana: Supercontinent Assembly and Breakup: Geological Society, London, Special Publications, 206, pp. 203-230.

Hochard, C., 2008. GIS and Geodatabases Application to Global Scale Plate Tectonics Modelling, PhD Thesis, University of Lausanne, Switzerland, 164 pp.

Hochard, Vérard, Baumgartner Stampfli, in preparation. Geodynamic evolution of the Earth over the Phanerozoic: Plate tectonic activity and palaeo-climatic indicators.

Hoepffner, C., Soulaimani, A., Piqué, A., 2005. The Morroccan Hercynides. Journal of African Earth Sciences 43, 144-165.

Hou, O., Zhao, Z., Zhang, H., Zhang, B., Chen, Y., 2006. Indian Ocean-MORB-type isotopic signature of Yushigou ophiolite in North Qilian in North Qilian Mountains and its implications. Science in China 49 (6), 561-572.

Jiang, G., Sohl, L.E., Christie-Blick, N., 2003. Neoproterozoic stratigraphic comparison of the Lesser Himalaya (India) and Yangtze block (south China): Paleogeographic implications. Geology 31, 917-920.

Jiang, Y.-H., Liao, S.-Y., Yang, W.-Z, Shen, W.-Z, 2008. An island arc origin of plagiogranites at Oytag, western Kunlun orogen, northwest China: SHRIMP zircon $\mathrm{U}-\mathrm{Pb}$ chronology, elemental and Sr-Nd-Hf isotopic geochemistry and Paleozoic tectonic implications. Lithos 106 (3-4), 323-335.

Johnston, S.T., 2008. The Cordilleran Ribbon Continent of North America. Annual Review of Earth and Planetary Sciences 36, 495-530.

Johnston, S.T., Borel, G.D., 2007. The odyssey of the Cache Creek terrane, Canadian Cordillera: Implications for accretionary orogens, tectonic setting of Panthalassa, the Pacific superwell, and break-up of Pangea. Earth and Planetary Science Letters 253, 415-428.

Jones, D.L., Silberling, N.J. Hillhouse, J., 1977. Wrangellia-A displaced terrane in northwestern. North America Canadian Journal of Earth Sciences 14 (11), 2565-2577.

Keppie, J.D., Nance, R.D., Murphy, J.B., Dostal, J., 2003. Tethyan, Mediterranean, and Pacific analogues for the Neoproterozoic-Paleozoic birth and development of periGondwanan terranes and their transfer to Laurentia and Laurussia. Tectonophysics $365,195-219$.

Keppie, J.D., Nance, R.D., Murphy, J.B., Dostal, J., Braid, J.A., 2010. The high-pressure Iberian-Czech belt in the Variscan orogen: extrusion into the upper (Gondwanan) plate? Gondwana Research 17, 306-316.

Key, R., Pitfield, P., Thomas, R., Goodenough, K., De Waele, B., Schofield, D., Bauer, W., Horstwood, M., Styles, M., Conrad, J., Encarnacion, J., Lidke, D., O'Connor, E. Potter, C., Smith, R., Walsh, G., Ralison, A., Randriamananjara, T., Rafahatelo, J.-M., Rabarimanana, M., 2011. Polyphase Neoproterozoic orogenesis within the East Africa - Antarctica Orogenic Belt in central and northern Madagascar. In: Van Hinsbergen, D., Buiter, S., Torsvik, T., Gaina, C., Webb, S. (Eds.), The Formation and Evolution of Africa: A Synopsis of 3.8 Ga of Earth History: Geological Society, London, Special Publications, 357, pp. 49-68.

Lardeaux, J.-M., Schulmann, K., Faure, M., Lexa, O., Janousek, V., Edel, J.-B., Stipska, P., 2012. Variscan orogeny in Bohemian Massif and French Massif Central, differences and similarities. Length scales, times scales and relative contribution of Variscan orogenic events to formation of European crust, Special meeting of French and Italian Geological Societies, Sassari: Géologie de la France, 1, pp. 168-170.

Laux, J., Pimentel, M., Dantas, E., Armstrong, R., Junges, S., 2005. Two Neoproterozoic crustal accretion events in the Brasília Belt, central Brazil. Journal of South American Earth Sciences 18, 183-198.

Leat, P., Dean, A., Millar, I., Kelley, S., Vaughan, A., Riley, T., 2005. Lithospheric mantle domains beneath Antarctica. In: Vaughan, A., Leat, P., Pankhurst, R. (Eds.), Terrane Processes at the Margins of Gondwana: Geological Society, London, Special Publications, 246 , pp. $359-380$

Li, Z.X., 1994. Collision between the North and South China blocks: A crustaldetachment model for suturing in the region east of the Tanlu fault. Geology 22 (8), 739-742.
Li, Z.X., Powell, C., 2001. An outline of the palaeogeographic evolution of the Australasian region since the beginning of the Neoproterozoic. Earth-Science Reviews 53, 237-277.

Li, Z.X., Li, X.H., Kinny, P.D., Wang, J., Zhang, S., Zhou, H., 2003. Geochronology of Neoproterozoic syn-rift magmatism in the Yangtze Craton, South China and correlations with other continents: evidence for a mantle superplume that broke up Rodinia. Precambrian Research 122 (1-4), 85-109.

Li, S., Kusky, T.M., Wang, L., Zhang, G., Lai, S., Liu, X., Dong, S., Zhao, G., 2007. Collision leading to multiple-stage large-scale extrusion in the Qinling orogen: Insights from the Mianlue suture. Gondwana Research 12 (1-2), 121-143.

Linnemann, U., Gerdes, A., Drost, K., Buschmann, B., 2007. The continuum between Cadomian orogenesis and opening of the Rheic Ocean: Constraints from LA-ICPMS U-Pb zircon dating and analysis of plate-tectonic setting (Saxo-Thuringian zone, northeastern Bohemian Massif, Germany). In: Linnemann, U., Nance, R.D., Kraft, P., Zulauf, G. (Eds.), The evolution of the Rheic Ocean: From AvalonianCadomian active margin to Alleghenian-Variscan collision: Geological Society of America Special Paper, 423, pp. 61-96.

Linnemann, U., Pereira, F., Jeffries, T.E., Drost, K., Gerdes, A., 2008. The Cadomian Orogeny and the opening of the Rheic Ocean: The diacrony of geotectonic processes constrained by LA-ICP-MS U-Pb zircon dating (Ossa-Morena and Saxo-Thuringian Zones, Iberian and Bohemian Massifs). Tectonophysics 461, 21-43.

Liu, Y.-J., Genser, J., Neubauer, F. 2005. 40Ar/39Ar mineral ages from basement rocks in the Eastern Kunlun Mountains, NW China, and their tectonic implications. Tectonophysics 398 (3-4), 199-224.

Liu, D., Jian, P., Kröner, A., Xu, S., 2006a. Dating of prograde metamorphic events deciphered from episodic zircon growth in rocks of the Dabie-Sulu UHP complex, China. Earth and Planetary Science Letters 250 (3-4), 650-666.

Liu, Y.-J., Neubauer, F., Genser, J., Takasu, A., Ge, X.-H., Handler, R., 2006b. 40Ar39Ar ages of blueschist facies pelitic schists from Qingshuigou in the Northern Qilian Mountains, western China. The Island Arc 15, 187-198.

Lu, S., Li, H., Zhang C. Niu, G. 2008. Geological and geochronological evidence for the Precambrian evolution of the Tarim Craton and surrounding continental fragments. Precambrian Research 160 (1-2), 94-107.

Lytwyn, J., Burke, K., Culver, S., 2006. The nature and location of the suture zone in the Rockelide orogen, Sierra Leone: Geochemical evidence. Journal of African Earth Sciences 46, 439-454

Martínez Catalán, J.R., 2012. The Central Iberian arc, an orocline centered in the Iberian Massif and some implications for the Variscan belt. International Journal Earth Sciences 101, 1299-1314.

Martínez Catalán, J.R., Fernandez-Suarez, J., Jenner, G.A., Belousova, E., Diez Montes, A., 2004. Provenance constraints from detrital zircon U-Pb ages in the Iberian Massif: Implications for Palaeozoic plate configuration and Variscan evolution. Journal of the Geological Society of London 161, 463-476.

Martínez Catalán, J.R., Arenas, R., Díaz García, F., Gonzáles Cuadra, P., Gómez Barreiro, J., Abati, J., Castiñeiras, P., Fernández-Suárez, J.. Sánchez Martínez, S., Andonaegui, P. Gonzáles Clavijo, E., Diéz Montes, A., Rubio Pascal, F.J., Valle Aguado, B., 2007. Space and time in the tectonic evolution of the northwestern Iberian Massif: Implications for the Variscan belt. In: Hatcher Jr., R.D., Carlson, M.P., McBride, J.H., Martínez Catalán, J.R. (Eds.), 4-D framework of continental crust: Geological Society of America Memoir, 200, pp. 400-423.

Martínez Catalán, J.R., Arenas, R., Abati, J., Sánchez Martínez, S., Díaz García, F., Fernández-Suárez, J., Gonzáles Cuadra, P., Castiñeiras, P., Gómez Barreiro, J., Diéz Montes, A., Gonzáles Clavijo, E., Rubio Pascal, F.J., Andonaegui, P., Jeffries, T.E., Alcock, J.E., Valle Aguado, B., Fernandez, R., Lopez Carmona, A., 2009. A rootless suture and the loss of the roots of a mountain chain: the Variscan belt of NW Iberia. Comptes Rendus Geosciences 341, 114.

Matte, P., 1991. Accretionary history and crustal evolution of the Variscan belt in Western Europe. Tectonophysics 180, 309-338.

Matte, P., 2001. The Variscan collage and orogeny (480-290 Ma) and the tectonic definition of the Armorica microplate: a review. Terra Nova 13, 122-128.

Mattern, F., Schneider, W., 2000. Suturing of the Proto- and Paleo-Tethys oceans in the western Kunlun (Xinjiang, China). Journal of Asian Earth Sciences 18 (6), 637-650.

Maus, S., Barckhausen, U., Berkenbosch, H., Bournas, N., Brozena, J., Childers, V., Dostaler, F., Fairhead, J.D., Finn, C., von Frese, R.R.B., Gaina, C., Golynsky, S., Kucks, R., Lühr, H., Milligan, P., Mogren, S., Müller, D., Olesen, O., Pilkington, M., Saltus, R., Schreckenberger, B., Thébault, E., Caratori-Tontini, F., 2009. Emag2: A 2-arcminute resolution Earth Magnetic Anomaly Grid compiled from satellite, airborne and marine magnetic measurements. Geochemical, Geophysics, Geosystems (G3) 10 (8) (12 pp., Q08005)

McDougall, N., Brenchley, P.J., Rebelo, J.A., Romano, M., 1987. Fans and fan deltas precursors to the Armorican Quartzite (Ordovician) in western Iberia. Geological Magazine 124 (04), 347-359.

McElhinny, M.W., Powell, C. Pisarevsky, S., 2003. Paleozoic terranes of eastern Australia and the drift history of Gondwana. Tectonophysics 362, 41-65.

Meert, J.G., 2003. A synopsis of events related to the assembly of eastern Gondwana. Tectonophysics 362, 1-40.

Meinhold, G., Arslan, A., Lehnert, O., Stampfli, G.M., 2010. Global mass wasting during the Middle Ordovician: Meteoritic trigger or plate-tectonic environment? Gondwana Research 19, 535-541.

Meinhold, G., Andrew, A.C., Avigad, D., 2013. New insights into peri-Gondwana paleogeography and the Gondwana super-fan system from detrital zircon $\mathrm{U}-\mathrm{Pb}$ ages. Gondwana Research 23 (2), 661-665.

Meng, X., Ge, M., 2003. Cyclic sequences, events and evolution of the Sino-Korean Plate, with a discussion on the evolution of molar-tooth carbonates, phosphorites and source rocks. Acta Geologica Sinica (English Edition) 77 (3), 382-401. 
Menold, C.A., Manning, C.E., Yin, A., Tropper, P., Chen, X.-H., Wang, X.-F., 2006. Metamorphic evolution, mineral chemistry and thermobarometry of orthogneiss hosting ultrahigh-pressure eclogites in the North Qaidam metamorphic belt, Western China, AGU Fall Meeting.

Michard, A., Hoepffner, C., Soulaimani, A., Baidder, L., 2008. The Variscan Belt. In: Michard, A., Saddiqi, O., Chalouan, A., Frizon de Lamotte, D. (Eds.), Continental Evolution: The Geology of Morocco. Springer Verl, pp. 65-131.

Moix, P., Beccaletto, L., Kozur, H., Hochard, C., Rosselet, F., Stampfli, G.M., 2008. A new classification of the Turkish terranes and sutures and its implication for the paleotectonic history of the région. Tectonophysics 451, 7-39.

Molnar, P., Tapponnier, P., 1975. Cenozoic Tectonics of Asia: Effects of a Continental Collision: Features of recent continental tectonics in Asia can be interpreted as results of the India-Eurasia collision. Science 189 (4201), 419-426.

Mugnier, J.-L., Cannic, S., Henriette, L., 2008. The tholeiites of the Valaisan domain (Versoyen, western Alps): a Carboniferous magma emplaced in a small oceanic basin. Bulletin de la Société Géologique de France 179, 357-368.

Murphy, J.B., Pisarevsky, S.A., Nance, R.D., Keppie, J.D., 2004. Neoproterozoic - Early Palaeozoic evolution of peri-Gondwanan terranes: implications for LaurentiaGondwana connections. International Journal Earth Sciences 93, 659-682.

Murphy, J.B., Gutiérrez-Alonso, G., Nance, R.D., Fernández-Suárez, J., Keppie, J.D. Quesada, C., Strachan, R.A., Dostal, J., 2006. Origin of the Rheic Ocean: rifting along a Neoproterozoic suture? Geology 34, 325-328.

Nance, R.D., Murphy, J.B., Keppie, J.D., 2002. A Cordilleran model for the evolution of Avalonia. Tectonophysics 352, 1-21.

Natal'in, B.A., Śengör, A.M.C., 2005. Late Palaeozoic to Triassic evolution of the Turan and Scythian platforms: The pre-history of the Palaeo-Tethyan closure. Tectonophysics $404(3-4), 175-202$

Okay, A.I., 2000. Was the late Triassic orogeny in Turkey caused by the collision of an oceanic plateau? In: Bozkurt, E., Winchester, J.A., Piper, J.D.A. (Eds.), Tectonics and Magmatism in Turkey and the Surrounding Area: Geological Society, London, Special Publications, 173, pp. 25-42.

Ouanaimi, H., Lazreq, N., 2008. The Rich Group of the Draa plain (Lower Devonian, AntiAtlas, Morocco): a sedimentary and tectonic integrated approach. In: Ennih, N Liégeois, J.P. (Eds.), The boundaries of the West African Craton: Journal Geological Society London, Special Issue, 297, pp. 467-482.

Owona, S., Mvondo Ondoa, J., Ratschbacher, L., Mbola Ndzana, S.-P., Tchoua, F., Ekodeck, G.-E., 2011. The geometry of teh Archean, Paleo- and Neoproterozoic tectonics in the Southwest Cameroon. Comptes Rendus Geoscience (Tectonics, Tectonophyics) $343,312-322$

Paixão, M., Nilson, A., Dantas, E., 2008. The Neoproterozoic Quatipuru ophiolite and the Araguaia fold belt central-northern Brazil, compared with correlatives in NW Africa In: Pankhurst, R., Trouw, R., Brito Neves, B., De Wit, M. (Eds.), West Gondwana Pre-Cenozoic Correlations Across the South Atlantic Region: Geological Society, London, Special Publications, 294, pp. 297-318.

Pereira, M.F., Chichorro, M., Johnston, S.T., Gutiérrez-Alonso, G., Silva, J.B., Linnemann, U., Hofmann, M., Drost, K., 2012a. The missing Rheic Ocean magmatic arcs: Provenance analysis of Late Paleozoic sedimentary clastic rocks of SW Iberia. Gondwana Research 22, 882-891

Pereira, M.F., Solá, A.R., Chichorro, M., Lopes, L., Gerdes, A., Silva, J.B., 2012b. NorthGondwana assembly, break-up and paleogeography: $\mathrm{U}-\mathrm{Pb}$ isotope evidence from detrital and igneous zircons of Ediacaran and Cambrian rocks of SW Iberia. Gondwana Research 22, 866-881.

Plissart, G., Monnier, C., Diot, H., Maruntiu, M., Neubauer, F., Demaiffe, D., Debaille, V., 2012. Recording of the easternmost Variscan ophiolitic complex: accretion and obduction of the Balkan-Carpathian oceanic crust (BCO - Romania, Serbia, Bulgaria) evidenced by Sm-Nd and Ar-Ar geochronology. Length scales, times scales and relative contribution of Variscan orogenic events to formation of European crust, Special meeting of French and Italian Geological Societies, Sassari: Géologie de la France, 1, pp. 168-170.

Qian, Q., Zhang, Q., Wang, Y., 2001. Early Palaeozoic North Qilian oceanic basin, an analogue to modern West Pacific; evidence from geochemical characteristics of ophiolites. InterRidge News 10 (1), 28-31.

Ramos, V., Vujovich, G., Martino, R., Otamendi, J., 2010. Pampia: A large cratonic block missing in the Rodinia supercontinent. Journal of Geodynamics 50, 243-255.

Ratschbacher, L., Hacker, B.R., Calvert, A., Webb, L.E., Grimmer, J.C., McWilliams, M., Ireland, T., Dong, S., Hu, J., 2003. Tectonics of the Qinling (central China); tectonostratigraphy, geochronology, and deformation history. Tectonophysics 366 (1-2), 1-53.

Ratschbacher, L., Franz, L., Enkelmann, E., Jonckheere, R., Pörschke, A., Hacker, B.R., Dong, S., Zhang, Y., 2006. The Sino-Korean-Yangtze suture, the Huwan detachment, and the Paleozoic-Tertiary exhumation of (ultra)high-pressure rocks along the TongbaiXinxian-Dabie Mountains. Special Paper, Geological Society of America 403, 45-75.

Reischmann, T., Anthes, G., 1996. Geochronology of the mid-German crystalline rise west of the River Rhine. Geologische Rundschau 85, 761-774.

Rodrigues, J., Pimentel, M., Dardenne, M., Armstrong, R., 2010. Age, provenance and tectonic setting of the Canastra and Ibiá Groups (Brasília Belt, Brazil): Implications for the age of a Neoproterozoic glacial event in central Brazil. Journal of South American Earth Sciences 29, 512-521.

Saki, A., 2010. Proto-Tethyan remnants in northwest Iran: Geochemistry of the gneisses and metapelitic rocks. Gondwana Research 17, 704-714.

Sanchez Martinez, S., Arenas, R., Gerdes, A., Potrel, A., Fernandez-Suarez, J., 2012. Considering a new tectonic setting for the Devonian ophiolites of the Variscan suture: isotope geochemistry and revised geochronology of the Purrido Ophiolite (Cabo Ortegal Complex, NEW Iberia Massif). Length scales, times scales and relative contribution of Variscan orogenic events to formation of European crust, Special meeting of French and Italian Geological Societies, Sassari: Géologie de la France, 1, p. 185.
Sánchez Martínez, S., Gerdes, A., Arenas, R., Abati, J., 2012. The Bazar Ophiolite of NW beria: a relic of the Iapetus-Tornquist Ocean in the Variscan suture. Terra Nova 24 (4), 283-294.

Schmidt, P., Powell, C., Li, Z.-X., Thrupp, G., 1990. Reliability of Palaeozoic palaeomagnetic poles and APWP of Gondwanaland. In: Schmidt, P., Van de Voo, R. (Eds.), Reliability of Palaeomagnetic Data: Tectonophysics, 184, pp. 87-100.

Schulz, B., von Raumer, J., 2011. Discovery of Ordovician-Silurian metamorphic monazite in garnet metapelites of the Alpine External Aiguilles Rouges Massif. Swiss Journal of Geosciences 104, 67-79.

Schwab, M., Ratschbacher, L., Siebel, W., McWilliams, M., Minaev, V., Lutkov, V., Chen, F., Stanek, K., Nelson, B., Frisch, W., Wooden, J.L., 2004. Assembly of the Pamirs; age and origin of magmatic belts from the southern Tien Shan to the southern Pamirs and their relation to Tibet. Tectonics 23, TC4002. http://dx.doi.org/10.1029/2003TC001583.

Scotese, C.R., Barrett, S.F., 1990. Gondwana's movement over the South Pole during the Paleozoic: evidence from lithological indcators of climate. In: McKerrow, W.S., Scotese, C.R. (Eds.), Palaeozoic Palaeogeography and Biogeograpahy: The Geological Society, pp. 75-85.

Śengör, A.M.C., 1979. Mid-Mesozoic closure of Permo Triassic Tethys and its implications. Nature 279, 590-593.

Shi, R.D., Yang, J.S., Wu, C.L., Wooden, J., 2004. First SHRIMP dating for the formation of the Late Sinian Yushigou ophiolite, north Qilian mountains. Acta Geologica Sinica 78, 649-657.

Shi, R., Yang, J., Wu, C., Tsuyoshi, I., Takafumi, H., 2006. Island arc volcanic rocks in the north Qaidam UHP belt, northern Tibet plateau: Evidence for ocean-continent subduction preceding continent-continent subduction. Journal of Asian Earth Sciences 28 (2-3), 151-159.

Skrzypek, E., Tabaud, A.-S., Edel, J.-B., Schulmann, K., Cocherie, A., Guerrot, C., Rossi, P. 2012. The significance of Late Devonian ophiolites in the Variscan orogen: a record from the Vosges Klippen Belt. International Journal of Earth Sciences Geologische Rundschau 101, 951-972. http://dx.doi.org/10.1007/s00531-011-0709-4.

Song, S.G., Yang, J.S., Liou, J.G., Wu, C.L., Shi, R.D., Xu, Z.Q., 2003. Petrology, geochemistry and isotopic ages of eclogites from the Dulan UHPM terrane, the North Oaidam, NW China. Lithos 70, 195-211.

Song, S.G., Zhang, L.F., Niu, Y.L., Su, L., Song, B., Liu, D.Y., 2006. Evolution from oceanic subduction to continental collision: a case study from the Northern Tibetan Plateau based on geochemical and geochronological data. Jounal of Petrology $47,435-455$.

Song, S.G., Zhang, L.F., Niu, Y., Wei, C.J., Liou, J.G., Shu, G.M., 2007. Eclogite and carpholite-bearing metasedimentary rocks in the North Qilian suture zone, NW China: implications for Early Palaeozoic cold oceanic subduction and water transport into mantle. Journal of Metamorphic Geology 25, 547-563.

Song, S., Niu, Y., Zhang, L., Wei, C., Liou, J.G., Su, L., 2009. Tectonic evolution of early Paleozoic HP metamorphic rocks in the North Qilian Mountains, NW China: new perspectives. Journal of Asian Earth Sciences 35, 334-353.

Spalla, M.I., Marotta, A.M., Rebay, G., Zanoni, D., Zucali, M., 2012. The transition from Variscan collision to continental break-up in the Alps: advices from the comparison between natural data and numerical model prediction. Length scales, times scales and relative contribution of Variscan orogenic events to formation of European crust Special meeting of French and Italian Geological Societies, Sassari: Géologie de la France, 1, pp. 202-203.

Stampfli, G.M., Borel, G.D., 2002. A plate tectonic model for the Paleozoic and Mesozoic constrained by dynamic plate boundaries and restored synthetic oceanic isochrons. Earth and Planetary Science Letters 196, 17-33.

Stampfli, G.M., Borel, G.D., 2004. The TRANSMED Transects in Space and Time: Constraints on the Paleotectonic Evolution of the Mediterranean Domain. In: Cavazza, W., Roure, F., Spakman, W., Stampfli, G.M., Ziegler, P. (Eds.), The TRANSMED Atlas: the Mediterranean Region from Crust to Mantle. Springer Verlag, pp. 53-80 (and CD ROM)

Stampfli, G.M., Hochard, C., 2009. Plate tectonics of the Alpine realm. In: Murphy, J.B. Hynes, A.J., Keppie, J.D. (Eds.), Ancient orogens and modern analogues: Geological Society, London, Special Publications, 327, pp. 89-111.

Stampfli, G.M., Kozur, H., 2006. Europe from the Variscan to the Alpine cycles. In: Gee, D.G., Stephenson, R. (Eds.), European lithosphere dynamics: Geological Society, London, Memoir, 32, pp. 57-82.

Stampfli, G.M., von Raumer, J., Borel, G.D., 2002. The Paleozoic evolution of pre-Variscan terranes: From peri-Gondwana to the Variscan collision. In: Martinez-Catalan, J.R., Hatcher, R.D., Arenas, R., Diaz Garcia, F. (Eds.), Variscan Appalachian Dynamics: the building of the Upper Paleozoic basement: Geological Society of America Special Paper, 364, pp. 263-280.

Stampfli, G.M., Vavassis, I., De Bono, A., Rosselet, F., Matti, B., Bellini, M., 2003. Remnants of the Paleotethys oceanic suture-zone in the western Tethyan area. In: Cassinis, G. Decandia, F.A. (Eds.), Stratigraphic and Structural Evolution on the Late Carboniferous to Triassic Continental and Marine Successions in Tuscany (Italy): Regional Reports and General Correlation: Bolletino della Società Geologica Italiana, Volume speciale 2, pp. $1-24$.

Stampfli, G.M., von Raumer, J., Wilhem, C., 2011. The distribution of Gondwana derived terranes in the early Paleozoic. In: Gutiérrez-Marco, J.C., Rábano, I., García-Bellido, D. (Eds.), The Ordovician of the World: Cuadernos del Museo Geominero, vol. 14. Instituto Geológico y Minero de España, Madrid, pp. 567-574.

Tang, H.-F., Liu, C.-Q., Nakai, S.i., Orihashi, Y., 2007. Geochemistry of eclogites from the Dabie-Sulu terrane, eastern China: New insights into protoliths and trace element behaviour during UHP metamorphism. Lithos 95 (3-4), 441-457.

Tapley, B., Ries, J., Bettadpur, S., Chambers, D., Cheng, M., Condi, F., Gunter, B., Kang, Z Nagel, P., Pastor, R., Pekker, T., Poole, S., Wang, F., 2005. CGM02 - An Improved Earth Gravity Field Model from Grace. Journal of Geodesy 11. http://dx.doi.org/ 10.1007/s00190-005-0480-z (11 pp.). 
Thiéblemont, D., Marcoux, E., Tegyey, M., Leistel, J.-M., 1994. Genèse de la province pyriteuse sud-ibérique dans un paléo-prisme d'accrétion? Arguments pétrologiques. Bulletin de la Société Géologique de France 165, 407-423.

Torsvik, T.H., Cocks, L.R.M., 2011. The Palaeozoic palaeogeography of central Gondwana. Geological Society, London, Special Publications 357, 137-166.

Torsvik, T.H., Van der Voo, R., 2002. Refining Gondwana and Pangea palaeogeography: estimates of Phanerozoic non-dipole (octupole) fields. Geophysical Journal International 151, 771-794.

Tung, K., Yang, H.-J., Yang, H.-Y., Liu, D.Y., Zhang, J.X., Wan, Y.S., Tseng, C.-Y., 2007. SHRIMP U-Pb geochronology of the zircons from the Precambrian basement of the Qilian Block and its geological significances. Chinese Science Bulletin 52 (19), 2687-2701.

Van Staal, C.R., Barr, S.M., Murphy, J.M., 2012. Provenance and tectonic evolution of Ganderia: Constraints on the evolution of the Iapetus and Rheic oceans. Geology 40, 987-990.

Vaughan, A., Leat, P., Pankurst, R., 2005. Terrane processes at the margin of Gondwana: Introduction. In: Vaughan, A., Leat, P., Pankhurst, R. (Eds.), Terrane Processes at the Margins of Gondwana: Geological Society of London, Special Publication, 246, pp. 1-22.

Vavassis, I., De Bono, A., Stampfli, G.M., Giorgis, D., Valloton, A., Amelin, Y., 2000. U-Pb and $\mathrm{Ar}-\mathrm{Ar}$ geochronological data from the Pelagonian basement in Evia (Greece): geodynamic implications for the evolution of Paleotethys. Schweizerische Mineralogische und Petrographische Mitteilungen 80, 21-43.

Veevers, J., 2007. Pan-Gondwanaland post-collisional extension marked by $650-500 \mathrm{Ma}$ alkaline rocks and carbonatites and related detrital zircons: A review. Earth-Science Reviews 83, 1-47.

Vérard, C., 2004. Palaeozoic Palaeomagnetism of South-Eastern Australia: Implications for the APW path of Gondwana. Fakultät für Geowissenschaften, München, LMU München (217 pp.).

Vérard, Hochard, Baumgartner, Stampfli, in preparation. 3D palinspastic reconstructions of the Phanerozoic versus sea-level and Sr-ratio variations.

Vérard, Stampfli, in press. Geodynamic Reconstructions of the Australides - 1: Palaeozoic

Vérard, Stampfli, submitted for publication. Geodynamic Reconstructions of the Australides - 2: Mesozoic - Cainozoic.

Vérard, C., Hochard, C., Stampfli, G.M., 2012a. Non-random distribution of euler poles: is plate tectonics subject to rotational effects? Terra Nova 24 (6), 467-476.

Vérard, C., Flores, K., Stampfli, G.M., 2012b. Geodynamic reconstructions of the South America-Antarctica plate system. Journal of Geodynamics 53, 43-60.

von Raumer, J.F., Schaltegger, U., Schulz, B., Stampfli, G.M., 2013. CGM02 - An Improved Earth Gravity Field Model from Grace. GSA Bulletin 125 (1/2), 89-108. http:// dx.doi.org/10.1130/B30654.1.

von Raumer, J., Stampfli, G.M., 2008. The birth of the Rheic Ocean - Early Paleozoic subsidence patterns and tectonic plate scenarios. Tectonophysics 461, 9-20.

von Raumer, J.F., Stampfli, G.M., Borel, G., Bussy, F., 2002. The organization of preVariscan basement areas at the north-Gondwanan margin. International Journal Earth Sciences 91, 35-52.

von Raumer, J., Stampfli, G.M., Bussy, F., 2009. The Variscan evolution in the External massifs of the Alps and place in their Variscan framework. Comptes Rendus Geosciences 341, 239-252.

von Raumer, J.F. Janoušek, V., Stampfli, G.M. 2012. Durbachites-vaugnerites - A timemarker across the European Variscan basement. Géologie de la France 1, 178-180.

Walliser, O., 1981. The geosynclinal development of the Rheinische Schiefergebirge (Rheno-Hercynian Zone of the Variscides; Germany). In: Zwart, H.J., Dornsiepen, U.F. (Eds.), The Variscan Orogen in Europe, Geologie en Mijnbouw, 89-96.

Wang, Z., 2004. Tectonic evolution of the western Kunlun orogenic belt, western China. Journal of Asian Earth Sciences 24 (2), 153-161.

Wang, J., Li, Z.-X., 2003. History of Neoproterozoic rift basins in South China: implications for Rodinia break-up. Precambrian Research 122 (1-4), 141-158.

Waters, C.N., Davies, S.J., 2006. Carboniferous: extensional basins, advancing deltas and coal swamps. In: Brenchley, PJ., Rawson, P.F. (Eds.), The geology of England and Wales. Geological Society of London, London, England, pp. 173-223.

Wilhem, C., 2010. Plate Tectonics of the Altaids. PhD Thesis, University of Lausanne, Switzerland, $347 \mathrm{pp}$.

Wilhem, C., Windley, B., Stampfli, G.M. 2012, the Altaids of Central Asia: a tectonic and evolutionary innovative review. Earth-Science Reviews 113, 303-341.

Wingate, M., Evans, D., 2003. Palaeomagnetic constraints on the Proterozoic tectonic evolution of Australia. In: Yoshida, M., Windley, B., Dasgupta, S. (Eds.), Proterozoic East Gondwana: Supercontinent Assembly and Breakup: Geological Society, London, Special Publications, 206, pp. 77-91.

Wu, H., Feng, Y., Song, S., 1993. Metamorphism and deformation of blueschist belts and their tectonic implications, North Qilian Mountains, China. Journal of Metamorphic Geology 11 (4), 523-536.

Wu, Y.-B., Hanchar, J.M., Gao, S., Sylvester, P.J., Tubrett, M., Qiu, H.N., Wijbrans, J.R., Brouwer, F.M., Yang, S.H., Yang, Q.J., Liu, Y.S., Yuan, H.I., 2009. Age and nature of eclogites in the Huwan shear zone, and the multi-stage evolution of the Qinling-Dabie-Sulu orogen, central China. Earth and Planetary Science Letters 277 (3-4), 345-354.

Xia, L.Q., Xu, X.Y., Xia, Z.C., Li, X.M., Ma, Z.P., Wang, L.S., 2003. Carboniferous postcollisional rift volcanism of the Tianshan Mountains, Northwestern China. Acta Geologica Sinica 7 (3), 338-360.
Xiao, W., Windley, B.F., Hao, J., Li, J., 2002. Palaeozoic evolution of central Asia Arcophiolite obduction in the Western Kunlun Range (China): implications for the Palaeozoic evolution of central Asia. Journal of the Geological Society 159, 517-528.

Xiao, W., Windley, B.F., Yuan, C., Sun, M., Han, C.M., Lin, S.F., Chen, H.L., Yan, Q.R., Liu, D.Y., Qin, K.Z., Li, J.L., Sun, S., 2009. Paleozoic multiple subduction-accretion processes of the southern Altaids. American Journal of Sciences 309, 221-270.

Xu, Z., Yang, J., Wu, C., Li, H., Zhang, J., Qi, X., Song, S., Qiu, H., 2006. Timing and mechanism of formation and exhumation of the Northern Qaidam ultrahigh-pressure metamorphic belt. Journal of Asian Earth Sciences 28 (2-3), 160-173.

Xue, F., Kroner, A., Reischmann, T., Lerch, F., 1996a. Palaeozoic pre- and post-collision calc-alkaline magmatism in the Qinling orogenic belt, central China, as documented by zircon ages on granitoid rocks. Journal of the Geological Society 153 (3), 409-417.

Xue, F., Lerch, M.F., Kroner, A., Reischmann, T., 1996b. Tectonic evolution of the East Qinling Mountains, China, in the Palaeozoic: a review and new tectonic model. Tectonophysics 253 (3-4), 271-284.

Yang, J.S., Robinson, P.T., Jiang, C.F., Xu, Z.Q., 1996. Ophiolites of the Kunlun Mountains, China and their tectonic implications. Tectonophysics 258 (1-4), 215-231.

Yang, J., Xu, Z., Zhang, J., Chu Ching, Y., Zhang, R., Liou Juhn, G., 2001. Tectonic significance of early Paleozoic high- pressure rocks in Altun-Qaidam-Qilian Mountains, Northwest China. Paleozoic and Mesozoic tectonic evolution of central Asia; from continental assembly to intracontinental deformation. Geological Society of America Memoir 194, 151-170.

Yang, J., Xu, Z.Q., Zhang, J.X., Song, S.G., Wu, C.L., Shi, R.D., Li, H.B., Brunel, M., 2002. Early Palaeozoic North Qaidam UHP metamorphic belt on the north-eastern Tibetan Plateau and a paired subduction model. Terra Nova 14 (5), 397-404.

Yang, J., Wu, C., Zhang, J., Shi, R., Meng, F., Wooden, J., Yang, H.-Y., 2006. Protolith of eclogites in the north Qaidam and Altun UHP terrane, NW China: Earlier oceanic crust? Journal of Asian Earth Sciences 28 (2-3), 185-204.

Yin, A., Nie, S., 1993. An indentation model for the North and South China collision and the development of Tanlu and Honam fault systems, eastern Asia. Tectonics 12 (4), 801-813.

Yin, A., Nie, S., 1996. A Phanerozoic palinspastic reconstruction of China. In: Yin, A., Harrison, T.M. (Eds.), The Tectonic Evolution of Asia. Cambridge University Press, Los Angeles, pp. 442-485.

Yoshida, M., Windley, B., Dasgupta, S., 2003. Proterozoic East Gondwana: Supercontinent Assembly and Breakup. Geological Society, London, Special Publication, 206 (473 pp.).

Yu, Z., Meng, Q., 1995. Late Paleozoic sedimentary and tectonic evolution of the Shangdan suture zone, eastern Qinling, China. Journal of Southeast Asian Earth Sciences 11 (3), 237-242.

Yuan, C., Yang, J., Zhou, H., Zhou, M., 2004. Nb-depleted, continental rift-related Akaz metavolcanic rocks, West Kunlun; implication for the rifting of the Tarim Craton from Gondwana. Geological Society, London, Special Publications 226, 131-143.

Yuan, H., Gao, S., Rudnick, R. L. Jin, Z Liu, Y Puchtel, I.S., Walker, R.J., Yu, R., 2007. Re-Os evidence for the age and origin of peridotites from the Dabie-Sulu ultrahigh pressure metamorphic belt, China. Chemical Geology 236 (3-4), 323-338.

Zhai, M., 2004. Precambrian tectonic evolution of the North China Craton. Geological Society, London, Special Publications 226 (1), 57-72.

Zhang, J.X., Yang, J.S., Mattinson, C.G., Xu, Z.Q., Meng, F.C., Shi, R.D., 2005. Two contrasting eclogite cooling histories, North Qaidam HP/UHP terrane, western China: petrological and isotopic constraints. Lithos 84, 51-76.

Zhang, G., Song, S., Zhang, L., Niu, Y., 2008. The subducted oceanic crust within continental-type UHP metamorphic belt in the North Oaidam, NW China: Evidence from petrology, geochemistry and geochronology. Lithos 104 (1-4), 99-118.

Zhang, J.-X., Mattinson, C.G., Meng, F.-C., Yang, H.-J., Wan, Y.-S., 2009. U-Pb geochronology of paragneisses and metabasite in the Xitieshan area, north Qaidam Mountains, western China: Constraints on the exhumation of HP/UHP metamorphic rocks. Journal of Asian Earth Sciences 35 (3-4), 245-258.

Zhao, Y., Liu, X.-H., Liu, X.-C., Song, B., 2003. Pan-African events in Prydz Bay, East Antartica, and their implications for East Gondwana tectonics. In: Yoshida, M., Windley, B., Dasgupta, S. (Eds.), Proterozoic East Gondwana: Supercontinent Assembly and Breakup: Geological Society, London, Special Publications, 206, pp. 231-245.

Zhou, J.-B., Wilde, S.A., Zhao, G.-C., Zheng, C.-Q., Jin, W., Zhang, X.-Z., Cheng, H., 2008. Detrital zircon U Pb dating of low-grade metamorphic rocks in the Sulu UHP belt: evidence for overthrusting of the North China Craton onto the South China Craton during continental subduction. Journal of the Geological Society 165 (1), 423-433.

Ziegler, P.A., 1988. Evolution of the Arctic-North Atlantic and the Western Tethys: American Association of Petroleum Geologists Memoir, 43, 198 pp.

Ziegler, P.A., Stampfli, G.M., 2001. Late Paleozoic Early Mesozoic plate boundary reorganisation: collapse of the Variscan orogen and opening of Neotethys. In: Cassinis, R. (Ed.), The continental Permian of the Southern Alps and Sardinia (Italy) regional reports and general correlations: Annali Museo Civico Science Naturali, Brescia, 25, pp. 17-34 